MACIEJ JANOWSKI

Tadeusz Manteuffel Institute of History, Polish Academy of Sciences, Warsaw

\title{
A MARRIAGE OF CONVENIENCE: THE ROMAN CATHOLIC CHURCH AND MODERNITY IN NINETEENTH-CENTURY EUROPE
}

\begin{abstract}
The article examines the problem of Dechristianization and secularization in nineteenth-century Europe, with a special emphasis on the Roman Catholic Church's ways of reacting to modernity. The Church managed to come to terms with modernity and to escape secularization at the price of supporting modern radical nationalism in the early twentieth century.

Keyw ords: Dechristianization, secularization, laicization, Roman Catholic Church, modernity, nationalism.
\end{abstract}

I would like to investigate the link between transformations in European Christianity - primarily Catholicism - occurring throughout the nineteenth century and the various modernization processes taking place on the continent. These problems will be examined with regard to the question of Dechristianization.

This reflection starts with the most general question: What happened to Christianity throughout the nineteenth century? Did anything special happen to it, or was it just one among many periods in the history of the Christian religion? Christianity did look different in 1914 and in 1789, that much is certain. Yet everything looks different at the beginning and at the end of any sufficiently long period. As I try to reflect on the nature of the problem itself, immediately numerous doubts emerge - even before the facts are tackled. Thus - what is the question really about? Below I shall try to present several perspectives from which we can view the phenomenon. ${ }^{1}$

${ }^{1}$ At various stages of its writing the paper was discussed in detail in the Department of the History of Ideas and Intelligentsia, Tadeusz Manteuffel Institute of 


\section{Nineteenth-century modernization and Christianity}

a) Let us begin with the transformations of religious experiences
throughout the century in question (and even longer than that). Let us assume a priori that the distribution of psychological attitudes is the same in various periods: the proportions of people who are hot and lukewarm, emotional and rational, extreme and moderate were the same in the nineteenth century as in any other century (although this may not be entirely correct: let us not forget what Johan Huizinga wrote about greater emotionality of people in the late Middle Ages). There is much evidence from the nineteenth century - like from many other periods - of experiences of people living profoundly religious lives. When it comes to Polish examples, we can read the memoirs of Jadwiga Zamoyska, wife of General Zamoyski, or - to refer to someone from another social sphere - the diaries of the writer Zofia Romanowiczówna. ${ }^{2}$ A very interesting source is a short study by Elżbieta Dębicka, Genealogia psychiczna (Psychological Genealogy), in which the author tries to analyse - using the psychological character theories of the inter-war period - the psychological profiles of her ancestors, who came from the Polish landed nobility. The problem of personal religiosity returns in the study in many analyses. ${ }^{3}$ People like the protagonists of the books given here as examples are individuals who experience their religiosity 'for themselves', which does not mean they are passive. They live, they make sacrifices in the name of their religion, offer their suffering to God - and no one knows about it, if they or their loved ones do not record such forms of religiosity in diaries or memoirs. The religiosity of such people is what Alfred Whitehead must have had in mind, when he wrote that 'religion is what the individual does with his own solitariness'. Obviously, there are also people who are religious in a more 'extrovert' manner, whose individually profound religiosity translates into a sense of social responsibility and often also public work done in the name of religion - they are easier to study, because they leave behind more sources.

Psychological experiences of individuals do not occur outside history. There are forms of spirituality specific to a given period and thus depen-

History, Polish Academy of Sciences. I am particularly grateful to Maciej Górny, Jerzy Jedlicki, Adam Kożuchowski and Krzysztof Niewiadomski.

${ }^{2}$ Jadwiga Zamoyska, Wspomnienia, ed. Maria Czapska, London, 1961; Zofia Romanowiczówna, Dziennik lwowski 1842-1930, ed. Zbigniew Sudolski, 2 vols, Warsaw, 2005.

${ }^{3}$ Elżbieta Dębicka, Genealogia psychiczna, ed. Jerzy Komorowski, Wrocław, 2012.

${ }^{4}$ Whitehead's definition is quoted by Gordon W. Allport, 'Jednostka i religia', transl. Anna Bartkowicz and Irena Wyrzykowska in idem, Osobowość i religia, Warsaw, 1988 (English original: The Individual and his Religion, New York, 1950), p. 144. 
dent on the type of culture. Romanticism witnessed a revival of religious emotionality (it would be interesting to examine how this wave of religious emotionality is connected to the previous waves: Baroque religiosity of the seventeenth century and late medieval devotio moderna). Scholars point to an increase in the number of private revelations, especially Marian apparitions, ${ }^{5}$ which have some characteristic features. The Blessed Virgin Mary appears to representatives of marginalized groups: women and children from rural areas or small towns, often representatives of national minorities. The Lourdes apparitions are the best example of this; in Poland these are features of, for example, the apparitions of Gietrzwałd, Warmia (Prussian Poland), in 1877. In addition, throughout the nineteenth century there emerged the practice of conducting missions in parishes; such missions were often an opportunity to manifest collective religious emotions on a large scale. We have numerous testimonies to how emotionally their participants reacted to the words, gestures and voice of popular preachers; to what extent this mood continued and to what it disappeared shortly after the end of the service is not clear. ${ }^{6}$

When considering the significance of transformations in individual religiosity to the subject of this paper, we need to take into account two more questions. If we ask about Christianization or Dechristianization, we come up against the following problem: Are these phenomena to be found in individual psychological processes or in social transformations? That individual religious life is rooted in social phenomena is something we know from Émile Durkheim, but here the question concerns something else: If an institutional religious movement is on the rise and the number of people with individual religious experiences is falling, are we dealing with Christianization or Dechristianization (in the long run)? Can we accept that social processes are NOT multiple individual processes or accept that when speaking of (De)Christianization, we mean a social and not psychological phenomenon? Can we imagine a (model) society in which NOBODY is internally religious but society is religious, because people 'enact the religious part' at the right moments or at least do not object when others enact it? Or, conversely, a society in which everybody is deeply religious internally, but represents pietistic religiosity focused on profound

${ }^{5}$ Gábor Klaniczay presented his research into nineteenth-century ecstatic religiosity in a very interesting lecture delivered at the History Department, Central European University in Budapest (13 November 2014). The lecture drew my attention to the problem in question. On the increasing popularity of private revelations in the nineteenth century, cf. also Daniel Olszewski, Kultura $i$ życie religijne społeczeństwa polskiego w XIX wieku, Lublin, 2014, pp. 274-76.

${ }^{6}$ Examples are given by Daniel Olszewski, Kultura i życie, pp. 240-55. 
individual experiences? Such society as a whole will not be religious, however, because it lacks grand public religious celebrations, because state ceremonies are secular and you cannot see from the outside whether the citizens observe social norms, because they are afraid of punishment, or because they are highly conscious as citizens, or because the moral norms of their religion are deeply internalized. Such a model approach is undoubtedly absurd, but the idea is to make the readers and oneself aware that individual religious life and social celebration of religion are two distinct phenomena and that their dynamics, to some extent, are different, even contradictory. ${ }^{7}$

Another, similar issue: contrary to the common-sense belief, often repeated (although probably by journalists rather than scholars), that unshakeable certainty of one's own opinions leads to fanaticism, it seems to me that it is the other way round - what leads to fanaticism is self-uncertainty. People who are the most intolerant of a behaviour are those who have problems with obeying the prohibition concerning this behaviour and observe it only with great difficulty, wrote Elliot Aronson. ${ }^{8}$ Gordon Allport, perhaps slightly idealistically, made a similar observation about the problem of religion, writing that religious fanaticism is one of the central signs of immature religiosity. ${ }^{9}$ A person or a group unshakably certain of the rightness of their worldview may be tolerant (is it not the case of the weak tendency to proselytize in Judaism?). If we conclude that his observation is apt (at least in some cases), it would be an argument in favour of the separateness of individual religiosity and religiosity as a social phenomenon, because fanatical and intolerant behaviours of representatives of a religion in the social sphere do not allow us to draw conclusion as to the depth of their faith.

It is very difficult to generalize about testimonies to individual experiences. They tell historians something only (or as much as) in the sense that they enable them intuitively to sense the vague limits of the possible in a given period: if we have only a single example of an attitude, we can only conclude with certainty that such an attitude was possible in this period.

${ }^{7}$ Theoretical reflections on the subject and a discussion of the huge literature on the subject can be found in overview-type studies like, for example, Katarzyna Zielińska, Spory wokót teorii sekularyzacji, Cracow, 2009; Günter Kehrer, Wprowadzenie do socjologii religii, transl. Janusz Piegza, 2nd edn, Cracow, 2006 (German original: Einführung in die Religionssoziologie, Darmstadt, 1988).

${ }^{8}$ Eliot Aronson, Człowiek - istota społeczna, transl. Józef Radzicki, Warsaw, 1978 (English original: Social Animal, San Francisco, 1972).

${ }^{9}$ Allport, 'Jednostka i religia', p. 151. In Allport's case this observation is part of a very interesting and extensive analysis of various forms of mature and immature religiosity; however, these issues must be left aside here. 
How frequent it was, we do not know, but it was possible. This is something, because it enables us to reconstruct the scale of possible behaviours: to extract from the infinite pool of theoretically possible human attitudes a finite area encompassing behaviours and feelings encountered in the period and culture that interest us. To sum up this point - it does not seem that any crisis of Christianity could be discerned in that period in individual religious life understood qualitatively. The quantitative question is another matter: how large was the group of individuals inaccessible to any religious experience? This question leads to another problem.

b) Deserving of separate treatment are intellectual transformations, important as both individual and social processes. Speaking of intellectual processes, I do not mean someone's discovery of rational reasons for non-belief (for there are no such reasons, as there are no rational reasons for belief). I mean here the creation of an intellectual/cultural atmosphere in which an increasing number of matters can/should be analysed without religious assumptions. In the Middle Ages everything could be thought and written about in religious terms. It is not that religion used repressive measures to narrow the possible sphere of thought and expression (though this may have been the case too), but on the contrary - that the religious paradigm was so broad and so attractive intellectually that within its framework it was possible to write about anything that could be interesting to a European intellectual at the time. Worthy of note here is one of the classic works of the Annales School Lucien Febvre's Le problème de l'incroyance au XVI siècle (1947). One of its main arguments is that it was not possible to be an atheist in sixteenth-century French culture - there was no category to express atheism. The thesis gave rise to some polemics, but it is useful for the purpose of the present analysis as it makes evident a certain problem: it is more or less difficult to express non-religious ideas in different cultures; in nineteenth-century culture it was becoming increasingly easy.

Let us take one of the most influential books criticizing religion in the name of the progress of reason - History of the Conflict Between Religion and Science by the American biologist John William Draper, published in 1874, and soon translated into French, German, Italian, Spanish, Polish, Russian, Portuguese and Serbian. ${ }^{10}$ If we tried (as Wilhelm Dilthey and other theorists of understanding humanities would recommend) to imagine the attitude of an intelligent reader of the book in the eighth or ninth decade of the nineteenth century, we could come to

${ }^{10}$ Owen Chadwick, The Secularization of the European Mind in the 19th Century, Cambridge, 1990 (1st edn 1975), p. 161. 
the conclusion that its persuasive effect results from two things: first, the huge amount of fact-based material. In addition to the phraseology originating in Enlightenment era anti-clericalism, the reader will find in it a whole range of clearly organized substantive data; irrespective of its polemical nature, the book must have been valuable as a vehicle popularizing the state of natural sciences at the time. The material must have impressed non-specialists in these sciences (like the present author and the majority of Draper's nineteenth-century readers).

This was something new. 'Science proves that religion is false' was a fresh thought that had not yet been made banal in popular anti-clerical propaganda. In the past anti-clericalism targeted moral abuses of the clergy, limitation by the Church of sexual and any other freedom, falsification of sacred books and incompatibility of their image of history with the critical source analysis method - now it could seem that a much more devastating argument had been found, an argument speaking through the calm power of facts, without reference to conscience, without rhetoric and so on. Moreover, after all, the argument (known as the cosmological argument) had been one of the leading arguments of the advocates of theism. Now - to use a military rhetoric - one of the heaviest cannons on the ramparts of the fortress had been seized by the attackers, turned 180 degrees and directed against the defenders. True - there were antecedents. The sense of the cosmological argument had already been challenged by David Hume in the eighteenth century (in his Dialogues Concerning Natural Religion). From a purely rational point of view, Hume's arguments were more profound than the arguments of any nineteenth-century anti-clerical, but were presented in a manner typical of Hume: calm, non-aggressive, slightly ironic. They could not have had a mass appeal. In addition, Hume's scepticism concerned the legitimacy of scientific as much as religious cognition, and as such could not provide this rhetorically very effective opposition between true science and false religion on which Draper's book is based.

Secondly, in Draper's case we have a clear possibility of interpreting the idea of progress as an anti-religious argument. This in itself is by no means new (to recall Nicolas de Condorcet), but here, too, the amassed fact-based material adds strength to the 'progress argument', strength it lacked in the late eighteenth century. Even if anti-religious nineteenth-century authors say things similar to those said by representatives of the Enlightenment in the eighteenth century - as Owen Chadwick writes - their persuasive power comes from the fact that they are not men of the Enlightenment but men of the laboratory: ${ }^{11}$

${ }^{11}$ Chadwick, The Secularization, p. 165. 
Science (with a capital ' $S$ '), Science itself speaks through them. The scientific achievements of the nineteenth century make it possible to write in a manner in which pride in one's accomplishments is combined with characteristic astonishment and contempt for the previous generations as well as those in our day who have not yet freed themselves from prejudice. 'Not without astonishment can we look back at what, in those times, were popularly regarded as criteria of truth. Doctrines were considered as established by the number of martyrs who had professed them, by miracles, by the confession of demons, of lunatics, or of persons possessed of evil spirits [...]. What an utter ignorance of the nature of evidence and its laws have we here!'. ${ }^{12}$

Such a method of persuasion worked; it created a new cultural reality, it made it possible to accept new ideas by an act of faith rather than the mind, but with a pleasant conviction that, in fact, they had rational foundations. At the same time it corresponded to the prevailing mood of liberal historiography, which, too, often expressed its amazement that people in the past could so easily have given in to tyrannical institutions (the Catholic Church being one of most important among them). We could also analyse the huge impact of Charles Darwin's theory of evolution (not wholly in line with its author's intentions) and the ideas, openly critical of religion, of the German physiologist Jacob Moleschott or the eminent naturalist Ernst Haeckel. They were the reason why Madzia Brzeska from Bolesław Prus' novel Emancypantki (The New Woman) of 1894, having learned of these ideas from a jaded friend, began to wonder in a moment of doubt whether perhaps the soul did not really exist and everything was determined by the 'phosphorus' of which our mind was made. In the $1880 \mathrm{~s}$ an English fourteen-year-old, quoted by Chadwick, wrote in his journal: 'Darwin has disproved the Bible!'. ${ }^{13}$ A cultural situation in which an intelligent pupil has such a conviction is an excellent example of the weakening influence of Christianity.

There is a huge body of evidence of similar attitudes; interestingly not only among triumphant positivists, but also among people who were worried (even sometimes despaired) because of the impossibility of faith in a rational era. We find this evidence - even more interestingly - among Christians, who acknowledged that science made it impossible to believe like in the old days and drew various conclusions from this fact.

12 John William Draper, History of the Conflict Between Religion and Science, New York, 1875, pp. 205-06.

${ }^{13}$ Chadwick, The Secularization, p. 164 (without giving either the source of the information or the name of the young man). 
How did this happen? Perhaps by asking about the mechanism and causes of Dechristianization, we are asking about the mechanism and causes of change in history - possibly the most difficult and the most inexplicable thing? If we were to look for an explanation, we should probably go back to the old thesis that the dominant attitude in the nineteenth century was largely scientistic-optimistic. This picture can so easily be challenged. Not only when we look at pessimists and sceptics, but also when we analyse in greater detail the writings of the classics of Victorian liberalism, authors like John Stuart Mill or Herbert Spencer, do we see their doubts and, at times, terror because of the direction in which civilization was developing. Yet when compared with earlier and later periods, it seems that the period from the Enlightenment until the last decades of the nineteenth century was indeed characterized by a dose of optimism about man's developmental possibilities (I deliberately leave aside Romanticism for the moment.)

It is also possible to paint a more complicated picture that would highlight doubt as one of the fundamental experiences of educated human beings in the nineteenth century. This doubt, and not naive optimism, would be a result of scientific development. ${ }^{14}$ Only after working through the crisis caused by doubt was it possible to arrive at an optimistic belief in science (or more profound religiosity). The idea of progress made it possible to restore the disrupted sense of the world order. Thus emerged entire subcultures in which non-belief - or at least rejection of confessional orthodoxies - was acceptable or even constituted the norm. Such a subculture at the turn of the twentieth century was certainly made up by young intellectuals from various European countries, supporters of many new political movements (above all social democracy) as well as artists and many scientists.

The idea of progress brings us to another - alongside scientism movement in nineteenth-century culture, of key importance to the subject matter in question, namely historicism. Religious phenomena, like any other phenomena, were subjected to 'historicization' - the neologism means more or less that all phenomena from now on were viewed as characteristic of the period and their culture. On the one hand this meant that they should not be criticized from the point of view of later periods, but must be understood in their own terms; on the other - that they should be relativized, that a given figure, social movement or idea was inextricably linked to its period. Such an approach with regard to Christianity produced one of the most famous - alongside those by Draper or

${ }^{14}$ Cf. Jerzy Jedlicki, Świat zwyrodniały. Lęki i wyroki krytyków nowoczesności, Warsaw, 2000, especially the subchapter ‘Ewolucja a postęp moralny’ (pp. 139-84). 
Haeckel - iconoclastic books in the nineteenth century, Ernest Renan's Life of Jesus. The book was read - in addition to Haeckel and many others - on the eve of the First World War by the protagonist of Jan Parandowski's famous novel Niebo w płomieniach (Heaven in Flames) of 1936: 'He kept reading urged by restless curiosity and a special kind of malice with which he now accepted everything that could contribute to undermining his faith. He took notes in a separate notebook and kept reading them to imprint them on his memory. They contained a mixture of contradictions found in the Gospels, problematic analogies between pagan and Christian rites, historical facts that could not be reconciled with the tradition of the Church, and unanswered questions'. ${ }^{15}$

If young people could - despite the disapproval of those around them - read similar books and accept their conclusions, this happened because, as Peter Berger, one of the most distinguished contemporary sociologists of religion writes, modernity pluralizes. ${ }^{16}$ It introduces a variety of possibilities; it opens up previously inaccessible paths. (This is not the place to wonder how this thesis relates to Zygmunt Bauman's well-known thesis that modernity introduces uniformization, that it transforms the world into a meticulously planned out and geometrized French garden. I think the two are not contradictory, but that they concern other issues). It is precisely in the categories of the opening of previously inaccessible paths of mental development (the most important among which have been mentioned above) that the potentially Dechristianizing nature of nineteenth-century culture lies - for an opening of paths does not determine the number of people deciding to follow them.

And now we move to the next period. Sometime in the last decade of the nineteenth century rational optimism (as much as it had existed before) collapsed. Let me once again refer to Parandowski, this time in a longer quotation. At a secondary school in Lwów, the last few years before the First World War, a new school year is about to begin. The teachers enter the building they know so well and are happy to conclude it has not

15 ‘Podtrzymywała go w tej lekturze niespokojna ciekawość i szczególny rodzaj złośliwości, z jaką teraz przyjmował wszystko, co mogło się przyczynić do pognębienia wiary. W osobnym kajecie robił notatki, które wciąż odczytywał, aby je utrwalić w pamięci. Mieszały się tam z sobą sprzeczności dostrzeżone w ewangeliach, kłopotliwe analogie obrzędów pogańskich z chrześcijańskimi, fakty historyczne nie dające się pogodzić z tradycją Kościoła, nie rozstrzygnięte pytania'; Jan Parandowski, Niebo w płomieniach, 13th edn, Warsaw, 1976, p. 103.

16 'Modernity is not necessarily secularizing; it is necessarily pluralizing', Peter L. Berger, 'Secularization Falsified', First Things, February 2008, pp. 23-27 〈http://www. firstthings.com/article/2008/02/002-secularization-falsified $\rangle$ [accessed 13 May 2015], (lecture delivered at the New School of Social Research, 10 October 2007). 
changed during the holidays - just as they would 'indignantly reject the thought that something should be changed in the ideas and facts making up their knowledge. Constructed, like the building itself, in the nineteenth century, it had not experienced any transformations and seemed so solid and reliable. It was rooted in the earth, the course of which in space was regulated by immutable laws of mechanics and the surface of which had revealed probably all its secrets to travellers, vessels and railways; it was cemented by matter, compact and exact in its indivisible atoms, locked in the periodic table like angels in unshakeable hierarchies; there was an even, calm order in it, an order which extracted solar systems from nebulae and which had once pushed the first cell onto the path of life. In its architecture the building seemed to resemble the knowledge professed within its walls. A clear layout of rooms and corridors, without any dark corners, a well- placed staircase, broad and bright, the whole within a compact quadrangle that seemed higher and more monumental than it was in fact, a degree of aristocratic bearing behind a fence, [...] blind windows at two corners, western and eastern, whence vexing draughts usually came - was it not a proper shape for the spirit resting among the goals achieved?... ${ }^{17}$

This slightly ironic description can be used as a model presentation of the nineteenth-century mind. 'In its indivisible atoms, locked in the periodic table like angels in unshakeable hierarchies' - this formula seems of key importance to me. There is an analogy between the rationalist structure of positivist science systems, and the rationalist structures of systems in medieval philosophy. Consequently, it is possible to defend the thesis that in the rationalist atmosphere of the nineteenth century, despite all the conflicts, Catholicism with its rationalism of neo-scholastic theology and

17 'odsunęliby ze zgorszeniem myśl, że należy coś zmienić w zakresie idei i faktów, z których składała się ich wiedza. Zbudowana, jak sam gmach, w XIX wieku, nie doznała od tej pory żadnych przeróbek, tak dalece wydawała się solidna i godna zaufania. Opierała się na ziemi, której bieg w przestworzach regulowały niezłomne prawa mechaniki, a której powierzchnia zdradziła chyba wszystkie swe tajemnice podróżnikom, okrętom i kolejom; na kształt cementu spajała ją materia, zwarta i ścisła w swych niepodzielnych atomach, zamkniętych w tablicy pierwiastków Mendelejewa, jak anioły w niewzruszonych hierarchiach; panował w niej równy, spokojny ład, który z mgławic odwija systemy słoneczne i który pchnął kiedyś pierwszą komórkę w tor życia. Gmach zakładu w swej architekturze miał pewne podobieństwo do wiedzy wyznawanej w jego murach. Przejrzysty rozkład sal i korytarzy, bez mrocznych zakamarków, dobrze osadzona klatka schodowa, szeroka i jasna, całość w zwięzłym czworoboku, który wydawał się wyższy i bardziej monumentalny, niż był w istocie, pewien arystokratyzm w odosobnieniu poza sztachetami, [...] ślepe okna w dwóch rogach, zachodnim i wschodnim, skąd przychodzą najrychlej dokuczliwe przeciągi - czyż nie był to właściwy kształt dla ducha wypoczywającego wśród osiągniętych celów?...'; Parandowski, Niebo w płomieniach, p. 118. 
anti-clericalism with its rationalism of modern scientism enjoyed a strange coexistence. Now this atmosphere had been destroyed: rationalism of both science and scholasticism had collapsed. The young man - the protagonist of Parandowski's novel - rebels against religion and scholasticism, but his rebellion is, in a way, also directed against the atmosphere at the school, against this 'spirit resting among the goals achieved'. And yet this atmosphere was created by all teachers, not only the prefect - the catechist.

Fin-de-siècle culture was both an opportunity and threat to religious life: an opportunity, because the decline of naive positivism opened up new prospects for religious emotionality. This mood of longing for mystery and metaphysics is felt by the protagonists of Wieczory nad Lemanem (Evenings on Lake Leman) (1893) - an apologetic dialogue by the Cracow Jesuit Marian Morawski. (Morawski himself was a very traditional Catholic, but he knew how to vividly present also those attitudes that were alien to him). A threat, because the moods of new irrationalism could spread in various directions, often hostile to religion - as is evidenced by the popularity of Friedrich Nietzsche in the early twentieth century.

Generally speaking, we have thus three cultural movements: scientistic positivism, historicism and irrationalism of the turn of the centuries (we should also add here romanticism, the influence of which in religious matters is similar to that of irrationalism). My impression is that among these three movements scientistic positivism, although most evident, was ultimately the least dangerous to religion; in any case, it declined in the 1890s. Historicism, which struck at the very idea of the immutability and timelessness of Christianity, and neo-romantic irrationalism, which repudiated the tradition of rational theology, were much more dangerous from the point of view of Christian (not necessarily only Catholic) orthodoxy. This does not mean that it was impossible to arrive at intellectual solutions making it possible to reconcile these trends with various forms of Christian orthodoxy - however, this required some philosophical effort as well as mental risk-taking of which Christians were not always capable.

c) Social transformations - intuitively they seem to be the most important, but if we look more closely, the matter becomes unclear. For precisely which social processes drive people away from religion? And which social processes were the most typical of nineteenth-century Europe? At first it seems that both questions have the same clear answer: uprooting. But does uprooting with its inner logic really lead to an abandonment of religion? ${ }^{18}$ After all, if I may engage in common-sense

${ }^{18} \mathrm{Cf}$. important and inspiring reflections on the subject in Chadwick, The Secularization, p. 93 ff. 
psychologizing for a moment, we could imagine a completely opposite mechanism: people uprooted from their traditional milieu may hang on tightly to their religion as the only element that is understandable and familiar in the new and strange world. People were being uprooted in every period - not by capitalist economic transformations, but by wars, natural disasters and other plagues. A revival of religiosity and not its decline was usually - and still is - a result of such disasters.

What does, therefore, make the capitalist uprooting different from the one caused by disasters? Perhaps its organized nature? Migrants from the countryside to cities, especially if they were factory workers, were caught - forgive me for the trite metaphor - in the 'whirl' of city life and the rhythm of this new life did not allow them to cultivate old behaviours. This happened especially when traditional religiosity was not internalized - and it was not probably in most cases - but was dictated by the social situation. As Allport writes, life crises have a tendency to just intensify the way of life that has been developing anyway.$^{19}$ Even if this is not a general rule, the phenomenon is certainly common. Those who migrated to cities moved from a community in which churchgoing was obvious to one in which they could abandon religion, and if they were not closely attached to it - they did abandon it. Thus we come back to the issue raised earlier: modernity introduced variety, it did not impose any attitudes when it came to religion, but presented various possibilities, introduced (through the very differentiation in social forms of management, even if we forget for a moment about the nineteenth-century liberal ideology) various ways of life. This is the situation of people who used to go to church only out of social conformity and out of the same conformity they ceased to attend it: the new conformity replaced the old one and the community became laicized $^{20}$ - or perhaps it would be more accurate to say that it did not become laicized but had been potentially secular before?

When analysing the decline of Christianity in Scotland in the nineteenth and first half of the twentieth century, Thomas Christopher Smout tries to go beyond the general remark concerning uprooting associated with migration and present a more in-depth analysis. He examines the following factors: the decline of belief in hell (the impossibility of understanding the Bible literally after Darwin); the development of social functions of the state making the Church's social work less needed; the replacement of

${ }^{19}$ Allport, 'Jednostka i religia', p. 135.

${ }^{20}$ Roger Aubert et al., Historia Kościoła, 5 vols, Warsaw, 1984-88 (French original: Nouvelle histoire de l'Église, Paris, 1965-78), (hereafter Historia Kościoła), vol. 5: 1848 do czasów współczesnych, 1985, p. 56. 
the idea of community (dominating in the rural areas) with the idea of class (the basis of the identity of the new urban proletariat); and, finally, 'the spread of other entertainment'. He stresses that this is not about the inability to respond intellectually to changes: the Church of Scotland adapted to the new times, said wise and important things, but its words 'fell on deaf ears'. This was accompanied by a slow waning of religiosity, which paved the way for its rapid decline from the 1960s onwards. Smout's books extends to 1950 and some processes were barely visible in the nineteenth century; nevertheless, such a view accurately captures some long-term tendencies. ${ }^{21}$

To this we should add 'technical' problems: cities, the growth rate of which had no parallels in the past (and few in later periods), were unable to keep up and develop its infrastructure accordingly - new housing emerged too slowly, as did the sewage system, city transport, health care and education system. Why should religious care be an exception here? Huge city parishes, with tens of thousands, sometimes even over one hundred thousand parishioners, were not an easy ground for pastoral ministry. On the other hand, the construction of a church in a laicized community could become a challenge releasing organizational energy - raising funds, attracting donors and so on - which could become the beginning of religious life in new conditions. ${ }^{22}$

The emergence of the urban proletariat was one aspect of social transformations; another, parallel one, was the rise of the bourgeoisie. Few other social groups in history have been the subject of so many superficial and schematic judgements, with their authors levelling all possible accusations, rarely heaping praise. It seems beyond doubt, however, that the success of the bourgeoisie is one of the social foundations of what I have described earlier as optimistic mood of the period. In this sense it provided the social base for the spread of scientistic attitudes negating the sense of and need for religion. On the other hand, it also seems beyond doubt that bourgeois culture was religious in its roots, associated primarily (not exclusively) with Protestantism. Which side prevailed? Again, it is hard to decide.

Finally, modernizing tendencies affected, to varying degrees, also the provinces - villages and small towns. European villages - even the backward villages of Galicia, not to mention more advanced regions of the

${ }^{21}$ Thomas Christopher Smout, A Century of the Scottish People 1830-1950, London, 1986, pp. 181-208 (chapter 'Churchgoing'). Both quotations from p. 208.

22 One example: Arlette Auduc, 'Une difficile construction d'église en banlieue: l'exemple de Sainte-Marthe des Quatre Chemins à Pantin (1875-1897)', Revue d'histoire de l'Église de France, 85, 1999, 215, pp. 291-314 〈http://www.persee.fr/web/revues/home/ prescript/article/rhef_0300-9505_1999_num_85_215_1372〉 [accessed 19 May 2015]. 
continent - were ultimately harnessed in the course of the nineteenth century into the international system of the capitalist economy. They became part of extensive market networks. This, however, did not affect the social and mental situation within the villages and small towns. The provinces became part of the world economy - but in many provincial regions and villages this undeniable fact was barely discernible. It is, thus, not surprising that in most provincial regions in Europe everything seemed 'fine' throughout the nineteenth century from the point of view of the Churches. Anthony Trollope's novels about the Anglican clergy in the fictitious cathedral city of Barchester and its environs, written in the third quarter of the nineteenth century, show a world that is stable and cheerful. The problems Trollope describes with friendly irony focus on marrying off daughters and efforts to obtain ecclesiastical offices. Social transformations are barely noticeable in this world, although - as we see with the benefit of hindsight - they are simmering under the surface. The first novel in the series, The Warden (1855), introduces an idealistic young man who accuses the warden of a church hospital of appropriating some funds allocated to its bedesmen. The young man is a doctor in the local hospital and has just returned to his home town after completing his medical studies in London. An important phenomenon can be seen here: there are no provinces isolated from the big world, because there are individuals who transmit processes from the centre to the peripheries.

An analogous example, not from fiction this time: a Czech scholar of social history has demonstrated how in Moravia in the early twentieth century anti-clerical ideas reached small towns and villages inhabited mainly by Czech-speaking Catholics, who lived on the margins of modernization processes. The ideas came from the outside, from Brno or other big cities; they did not find any strong local support and basically changed nothing. Everything seems to remain the same: the young radical from Trollope's novel eventually marries the warden's daughter and the anti-clerical Czech nationalist, speaking at a meeting in the Moravian town, when his listeners make the sign of the cross on hearing bells, has to make the sign as well, because he knows that otherwise he would lose any chance for winning his audience's trust. ${ }^{23}$

Yet something does change: both the protagonist of The Warden and the Moravian anti-clericals described by Lukaš Fasora can hope for support among individuals in the small town community. When the condi-

${ }^{23}$ Lukaš Fasora, 'Sociální souvislosti procesu sekularizace v málych komunitách v letech 1890-1913', in Sekularizace českých zemí v letech 1848-1914, ed. idem, Jiří Hanuš and Jiří Malír, Brno, 2007, pp.35-48. 
tions change, when social change reaches the small towns (for this will eventually happen, although in most cases after the final date I have adopted for this study), then the group of those 'misfits', standing outside the traditional structure of the local community and ready to support the impulses coming from the outside, may grow considerably and as a result it may (although does not have to) turn out that the traditional religiosity of the provinces has very frail foundations and breaks down fairly quickly.

For Christian denominations social and intellectual changes brought with them a threat of losing the masses and of losing the elites. Which of these threats was more direct in the nineteenth century? In his book Chadwick stresses what may seem incredible from the Polish perspective: in Victorian England Christianity was being abandoned by the masses (urban masses, of course) rather than by the elites. A worker who would attend an (Anglican) church or a (Methodist) chapel put himself at risk, as Chadwick writes, of becoming an oddity in the eyes of his friends and of being suspected of trying to be seen as someone from a higher social stratum, someone who aped the behaviour of the upper classes. ${ }^{24}$

I cannot say to what extent this mechanism worked in other environments and other parts of the continent. The English working class seemed to have been aware of its collective distinctiveness to a greater degree than workers from continental Europe (to recall Smout: identification with the class replaced identification with the community). This stemmed - as Edward P. Thompson once demonstrated in his excellent book The Making of the English Working Class (1965) - not from the impact of Marxism, to which English workers were very immune, but from the strength of the tradition of English radicalism, the sources of which were to be found in the seventeenth century, the period of the English Revolution and Civil War. English workers, rooted in the tradition of liberties they were entitled to as 'Freeborn Englishmen', founded associations and voiced demands concerning social and political changes although this activism had religious roots, as the nineteenth century progressed, it became increasingly secular, while both the Church of England and the once radical Methodist movement were increasingly seen as part of the traditional establishment.

However, the situation on the continent seemed to be slightly different - workers, even those educated by social democrats in the German Empire in the last quarter of the nineteenth century, were less conscious of class-based community and more dependent on their old

${ }^{24}$ Chadwick, The Secularization, p. 102. 
rural communities (for industrialization took hold later than it had in Great Britain and so old bonds had not yet completely dissolved). In any case, in countries less industrialized than Great Britain workers formed a smaller group within society. The Warsaw workers from the turn of the twentieth century kept not only their religion, but also traditional folk customs associated with it, which they had brought from their villages to the city. Memoirs and other accounts suggest that for them the Church was a kind of escape from the burdens of daily life.$^{25}$ Intuitively, I would suspect that in most of Europe non-belief in the nineteenth century was above all a matter of the elites as well as a relatively small part of the public at large.

I have room here for only a brief reference to the specificity of the United States of America, where the construction of a modern capitalist society did not entail - as Alexis de Tocqueville noted already in the 1830 s - a decline of religiosity, while religious institutions, decentralized and varied, were themselves an element of American democracy based on the strength of associations and local institutions.

d) Another question worth considering is political transformations, namely the emergence of the modern state. Many sociological studies devoted to the problem of secularization focus on points $b$ ) and c) referred to above. Chadwick's excellent book, too, an invaluable guide to the topic of the present study written from the British perspective, basically omits the question of the impact of state policy on religious life. And yet even the most perfunctory analysis of the nineteenth century reveals the huge significance of the conflict between the emerging modern state and the Church (mainly, but not only, the Catholic Church, for which the conflict was particularly acute given the Church's universality and hence supranational structure). The German Kulturkampf, the source of the general and still used name for the phenomenon (currently more often encountered in its English version, culture wars), is only the best known example of the phenomenon, which had existed at least since the Enlightenment. At least - for it could be said that tension between the secular and the spiritual authority is ingrained in the world of Western Christianity and that the conflict, culminating in the medieval fight between the empire and the papacy, determined the development of the idea of freedom in Europe, as none of the sides managed to win, but each was strong enough to prevent the other from winning (as Lord Acton claimed in the nine-

${ }^{25}$ Anna Żarnowska, Robotnicy Warszawy na przełomie XIX i XX wieku, Warsaw, 1985, pp. 178-180. 
teenth century, transferring the British constitutional theory of checks and balances to the development of political life of the entire continent). The early modern disputes surrounding Gallicanism in France can be regarded as part of the same trend as well. However, if we leave aside these antecedents, enlightened absolutism opened a new era - especially, when it came to the policy referred to as Josephinism. Old areas of conflict had revolved mainly around the monarch's supervision of the Church's public activities: the question of the monarch's influence on nominations of bishops, control of their contacts with the Holy See and the question of the so-called placetum regium, that is the monarch's control over the publication in a given state of bulls and other papal documents. To this were now added matters that were much broader and, in general, much more difficult to resolve through a compromise solution. These included control over schools and - gradually - movement of the population, above all the conditions for marriage and divorce. In addition, there now emerged the question of social usefulness of the clergy, which the 'age of lights' considered to be the central criterion of the raison d'être for any institution. The practical effects of this last issue included closure of monasteries, especially contemplative ones, considered 'useless', and the requirement for the Church to take over, on the parish level, some of the tasks of the state administration, still too weak to cope with them. In addition to registering population movements, as mentioned above, this consisted in disseminating the government's ordinances as well as collecting statistical data (in the Enlightenment meaning of the word, broader than today's) about parishes.

A model example of such a competence dispute can be the conflict between the Church and the government of the Duchy of Warsaw and the constitutional Kingdom of Poland in the first few years of its existence after 1815. Parish priests were now required to read out official ordinances from the pulpit; the dispute also concerned the keeping of birth, marriages and death registers (a major conflict over civil marriages in the Duchy of Warsaw) and the influence of the government on appointing bishops. The royal decree of 6/18 March 1817, 'On the degree of the government's supervision and care of the clergy' (the very phrasing of the title is characteristic) made it possible to file complaints against parish priests to the Minister of Religious Confessions and Public Enlightenment. ${ }^{26}$ The minister, Stanisław Kostka Potocki, one of the main exponents of the Polish Enlightenment, had to resign, as we know, as a result of the conflict in question.

${ }^{26}$ Anna Barańska, Między Warszawa, Petersburgiem i Rzymem. Kościół a państwo $w$ dobie Królestwa Polskiego, Lublin, 2008, pp. 470-71. 
Throughout the nineteenth century such conflicts erupted in practically every country with a strong Catholic presence. Their nature varied and - importantly and interestingly - they could be an expression of various attitudes and ideologies. Firstly, they were, obviously, an expression of anti-clerical liberalism, secondly - of Protestant anti-Catholic prejudice, finally - of simple political traditionalism, an attempt by the traditional elites to keep their hold over society. This is how one of the most distinguished experts on Hungary's political system, László Péter, interprets the so-called Hungarian Kulturkampf of the 1890s. In his view, the fight between the liberals ruling Hungary and the Church was part of a broader pattern of Hungary's development after 1867: the liberal-constitutional form became an instrument of the traditional aristocratic elites, which used it to block the country's democratization, undermining any initiatives not controlled by the state, including the activity of the Catholic Church. ${ }^{27}$ Elements of such a model can be found in many cases - they were usually combined with other motives highlighted earlier. In his mind Otto von Bismarck clearly combined traditional Protestant prejudice with a conservative belief that the Catholic Church was a threat to the hierarchical order through its control over the mass of its fanatically religious members (Bismarck wrote about the demokratischer Jesuitismus' ${ }^{28}$ of his Catholic opponents). German national liberals, like, for example, Heinrich von Sybel, found a different source for their étatiste ideas than Bismarck in a conviction which could be genetically traced back to Thomas Hobbes' thought that a modern state with full sovereignty was a condition of the freedom of the individual, for only such a state was capable of liberating the individuals from their fetters. The classic textbook of legal and political science by the eminent liberal Swiss lawyer Caspar David Bluntschli provides an excellent example of such a liberal-étatiste (and clearly misogynistic) way of thinking. Elements of the demonization of Catholicism are nearly the same in the case of Sybel or many other German 'national liberals' as in the case of Bismarck, a conservative. ${ }^{29}$

${ }^{27}$ László Péter, 'Church-State Relations and Civil Society in Hungary. A Historical Perspective,' in idem, Hungary's Long Nineteenth Century. Constitutional and Democratic Traditions in a European Perspective. Collected Studies, ed. Miklós Lojkó, Leiden and Boston, 2012, pp. 405-37; idem, 'Hungarian Liberals and Church-State Relations', in Hungary and European Civilization, ed. György Ránki, Budapest, 1989, pp. 79-138.

${ }_{28}$ Otto von Bismarck, Gedanken und Erinnerungen, 3 vols, Berlin and Stuttgart, 1921-22, vol. 3, p. 163.

${ }^{29}$ Michael B. Gross, 'Kulturkampf and Unification: German Liberalism and the War Against the Jesuits', Central European History, 30, 1997, 4, pp. 545-66 <http://www. jstor.org/stable/4546748> [accessed 23 March 2015]. 
A melancholic thought arises at this point: the conflict presented above was in some sense inevitable or (even with the utopian assumption of the best of wills on both sides) very difficult to avoid or solve. The modern state took over control over more and more areas of life: not because of greediness, desire for power or, generally, free choice, but owing to, as Montesquieu would say, "necessary relations arising from the nature of things'. Technological and social changes (as well as ideological changes, but when it comes to the origins of this particular phenomenon their role does not seem to have been central) give rise to new spheres of life that simply have to be controlled. The best commonsensical example is probably the highway code, which is not indispensable (perhaps with the exception of some rudiments) as long as the density of vehicles and their average speed do not cross a critical threshold - after which we cannot function without it. As a norm the essence of which is not specific content but its common observance (it does not matter whether we drive on the left or on the right side of the road, it is important for all of us to be driving on the same side), it has to be imposed by the government.

Moving to questions closer to the subject matter of the present study - an increasingly complex economic life made increasingly complex tax systems (and with them control systems) necessary, which implied the need for state supervision of demographic changes; marriage became a domain of the secular and not just spiritual authority. The development of institutions of social and economic life entailed providing a level of education for the masses as a prerequisite for functioning in society - this made the school an increasingly important institution and the object of a dispute between the Church (Churches) and the state. No one planned this, there was no all-encompassing Masonic conspiracy to oust the Church from public life, just as there was no Jesuit-clerical conspiracy to stop the changes. Yet there was an impression on both sides that the conflict was generated by the ill will of the other side, while in fact the ill will at most strengthened the conflict arising outside the awareness of those involved in it.

However, this picture of a bitter conflict will be softened, if we take into account two important extenuating factors. Firstly, the nineteenth-century state, that is the emerging modern bureaucratic state, oscillating in its attitude to Churches and religion between hostility, tolerance and collaboration, could not in any way do without elements of religious legitimization (with a possible exception of the French Third Republic). In describing Minister S.K. Potocki's attitude in the Kingdom of Poland after 1815, Anna Barańska writes that he did not seek the destruction of the Church but its 
'étatization' ${ }^{30}$ This apt term perfectly conveys the essence of the matter. An excellent example of this fragile equilibrium, collaboration combined with conflict - which, however, none of the sides wanted to escalate, because each had too much to lose - is the French Second Empire and the cult of St Napoleon ${ }^{31}-$ a rather amusing combination of the interests of the altar and those of the throne. I think that such a model of fragile equilibrium was typical of nineteenth-century relations between the state and the Church, unlike the model of a strong 'secular' state, like in the case of the French Third Republic after the laws of 1905.

Secondly, it would be one-sided if we saw this tendency to expand state authority only as an attack on the Church's privileges. In the eighteenth century, in particular, many ideas of enlightened reformers were supported by reformist Catholic theologians. In Germany, a situation favourable to Josephinist reforms was created by a movement referred to as Febronianism (from the pseudonym Febronius used by the auxiliary bishop of Trier, Johannes von Hontheim, when he published his work on the limits of papal power over bishops). Johannes von Hontheim spoke of a need for greater independence of bishops from Rome; from this perspective Josephinist concepts may have seemed conducive, because by undermining papal authority over the Church in the Habsburg states, they strengthened the position of the various bishops (although on the other hand, they left them without Roman protection vis-à-vis the state). Joseph II's numerous initiatives to reform religious orders, simplify the liturgy, direct the Church's attention to the practical life of the faithful - all these were problems preoccupying enlightened theologians and Church dignitaries in German-speaking countries in the second half of the eighteenth century. Josephisim was the work of theologians and 'every ordinance of this emperor was inspired by a theologian or a canonist,' writes the French historian of the Church Louis J. Rogier. ${ }^{32}$ Such a view of Josephinism as essentially a form of enlightened Catholicism is certainly one-sided - but as a point of view may be admissible and reveals something important. The French Revolution exacerbated the conflict and made the position of the Catholic advocates of reform more difficult, but it did not do away with such attitudes, visible, for example, in German countries in the first half of the nineteenth century.

${ }^{30}$ Barańska, Między Warszawa, Petersburgiem i Rzymem, p. 489.

${ }^{31}$ An excellent study: Sudhir Hazareesingh, 'Religion and Politics in the Saint-Napoleon Festivity (1852-1870): Anti-Clericalism, Local Patriotism and Modernity', English Historical Review, 119, 2004, 482 (June), pp. 614-49.

${ }^{32}$ Historia Kościoła, vol. 4: 1715-1848, p. 102. 
If so, if the modern state's efforts to 'oust' Catholicism from some of its positions were not always characterized by hostility to Christianity, then it will come as no surprise that their effects cannot be unambiguously classified either. It seems that the mechanism at work here was similar to that of the social transformations presented above. On the one hand, the state made it easier to abandon religiosity, because it created a situation in which religiosity was no longer the only option accepted by society (this assertion is not changed by the fact that in most cases the state fighting against the Church did not try to challenge mass religiosity - the fact that the conflict existed was hard to hide and the fact itself made religiosity cease to be something obvious). The emancipation of state institutions from the influence of the Church, even if it unfolded peacefully, was an important phenomenon when it came to abandoning religiosity. This is because emancipation reduced the necessary contacts with religious institutions. The process obviously did not have an impact on consciously religious people, but for those who were potentially religiously indifferent it opened up a possibility of living not so much against ecclesiastical institutions but outside them (again, the 'change of conformities' discussed before).

On the other hand, liberation from the burden of direct administrative functions boosted the moral authority of the Church in the long run and saved it from the upheavals affecting secular institutions in the nineteenth and twentieth centuries, and from a possible embarrassment, which would have most likely happened as a result of abuses and administrative ineptitude. It is impossible to balance out the mutual significance of both these tendencies.

Thomas Nipperdey points out that the building of the modern state had an indirect impact on the internal structure of the Catholic Church: it became 'defeudalized' at least to some extent. It lost some of its estates, various ecclesiastical institutions were made more or less dependent on the state, bishops saw their income and political standing decline. All this facilitated an unprecedented centralization of the Church under ultramontane slogans, which occurred - as will be discussed later - during Pius IX's pontificate. ${ }^{33}$

There is one more question concerning the four points analysed above that should attract our attention: if religiosity erodes as a result of (social, intellectual or political) transformations, what replaces it? A different kind of religiosity perhaps? Włodzimierz Pawluczuk studied the activities of Protestant religious groups in Belarusian villages near

${ }_{33}$ Thomas Nipperdey, Deutsche Geschichte 1800-1866, Munich, 1998, p. 407. 
Białystok in the inter-war period and examined their popularity in the context of the transformations affecting - as the title of his book puts it - 'the worldview of the individual in a disintegrating traditional community'. ${ }^{34}$ Yet in the nineteenth century religion was more often - it would seem replaced by new political ideologies. Nationalism and socialism were probably the most important among them. I would not tackle here the important and complex problem of secular religions. Can Marxism be regarded as a parareligion? Is nationalism not simply a secularized Christianity? For the practical purpose of the present study let us assume (without resolving the issue) that religion refers to an extra-terrestrial reality accepted as certain by its followers. Thus it is enough to remind ourselves that the new ideologies took over and transformed some elements of Christianity: many have written about the similarities between the Marxist philosophy of history, and Jewish and Christian eschatology; many have also pointed out how much nationalist language and rituals borrowed from the Christian language and rituals. At least to some extent these two ideologies, without being religions in the strict sense of the word, functionally replaced religion in the worldviews of individuals.

At the same time nationalism and socialism did not forgo the support of traditional religions. It is a testimony to the strength of nineteenth-century Christianity that both nationalist and socialist ideas entered into a symbiosis of one sort or another with selected and reinterpreted Christian ideas. How this process looked from the point of view of the Catholic Church will be discussed later; here I would only like to note that not only the existing state authorities but also 'anti-establishment' movements, national and social, used Christian symbolism, sometimes embarking on a deeper reflection on the relation between their own and Christian ideals.

\section{The Catholic Church responds to modernity}

So far I have been trying to outline processes unfolding in society as a whole, now let us look at the response to them on the part of Christians (focusing on the Catholic Church). A general, textbook-like pattern, would probably look as follows: the Church, after a period of Baroque and Counter-Reformation triumphs, was completely surprised by the new Enlightenment ideas and was unable to do anything apart from reiterating its opposition. This stance became even more rigid following the French Revolution, seen by people of the Church as a natural outcome of the En-

${ }^{34}$ Włodzimierz Pawluczuk, Światopogląd jednostki w warunkach rozpadu społeczności tradycyjnej, Warsaw, 1972. 
lightenment, and its culmination came during the pontificate of Pius IX (1846-78) and the First Vatican Council, with its emphatic confirmation of the traditional teaching in the form of the dogma of papal infallibility. It was not until the pontificate of Leo XIII than the Church began to respond to the problems caused by social and ideological changes of the preceding one hundred years (the encyclical Rerum novarum, 1891). Since then the Church has tried - though hesitantly (witness the fight against modernism during Pius X's pontificate) - to respond in one way or the other to the changing challenges of new eras until today.

However, this picture is too generalized. First of all, it fails to take into account the huge legacy of the Catholic Enlightenment. ${ }^{35}$ It is true that as a coherent worldview, it collapsed with the atrocities of the French Revolution. Yet its ideas did not disappear; they remained for a long time throughout the nineteenth century, especially in German-speaking countries. In a way, they inspired various movements seeking, in the nineteenth century and the early twentieth century, to reform the Church - liberal Catholicism and the Christian social movement as well as, in a slightly less direct manner, Catholic modernism. This was possible because already before 1789 there grew in strength Catholic Enlightenment ideas, influenced by Protestant pietism and the fashion for sentimentalism, valuing religious feeling above 'cold' reasoning. The ideas grew even stronger in the first decades of the nineteenth century under the impact of the triumphing Romanticism.

Secondly, the picture does not take into account change- and reform-minded tendencies, which existed in the Church throughout the period in question. The world is more complex that the textbook picture suggests.

Finally, there is a tendency in historiography to revise opinions about attitudes usually considered to be thoughtlessly traditional a tendency to view Pius IX's policy not as clinging to old forms but as a policy of a unique - very unique - modernization of the Church. When Olaf Blaschke was writing his now classic article about the nineteenth century as the second era of confessionalization, ${ }^{36}$ what he meant in a more general sense was the power of religion in the nineteenth

${ }^{35}$ Richard Butterwick-Pawlikowski ('Między oświeceniem a katolicyzmem, czyli o katolickim oświeceniu i oświeconym katolicyzmie', Wiek Oświecenia, 30, 2014, pp.11-55) provides an overview of the latest positions in historiography and an interesting suggestion of a conceptual distinction between 'Catholic Enlightenment' and 'enlightened Catholicism'.

${ }^{36}$ Olaf Blaschke, 'Das 19. Jahrhundert: Ein Zweites Konfessionelles Zeitalter?', Geschichte und Gesellschaft, 26, 2000, 1, pp. 38-65. 
century, and in a more particular sense - the role of the 'confession' that is faith, which again, like in the seventeenth century, was becoming increasingly, together with democratization, a marker of attitudes in political and cultural matters. We can, however, also speak about the nineteenth-century confessionalization, drawing on the classic approaches to the problem of early modern confessionalization - as a policy of centralization and political-religious 'uniformization'. In this context Pius IX's policy seeking to make Catholicism more 'rigid', both in the doctrinal and administrative sense, would be precisely an example of the new confessionalization. Ultramontanism, on the other hand, would not be - as it usually assumed - a traditionalist movement, but a part of this centralizing modernization of the Church, thus an ecclesiastical equivalent of the construction of the centralized secular state. Such an interpretation is not entirely convincing, but is worth considering.

In his very interesting study Christopher Clark analyses the religious revival of Catholicism in the nineteenth century, referring to the category of modernization. ${ }^{37}$ He polemicizes with those scholars who make a distinction between modern means and non-modern ends, and when it comes to the entire history of the nineteenth-century Church, they see at most a fight against modernity with modern methods. Liberal modernity is not its only variety, as Clark writes. By and large, such views can only be applauded. Shmul N. Eisenstadt's classic text of 2000, Multiple modernities, provides us with interpretation categories, drawing our attention to the multiplicity of forms in which modernity can be manifested - today's Muslim fundamentalism is no less modern than liberal democracy. Yet if we treat the Church as a 'modern' actor on the nineteenth-century stage, an approach such as the one presented above can blur the difference between the pontificates of Pius IX, his predecessors and the times of his successor, the difference that was evident to his contemporaries and that should not be missed. I believe, therefore, that the schematic picture presented at the beginning of this section should not be rejected in its entirety. Indeed, it seems evident that until the 1870 s the Church remained rather helpless vis-à-vis modernity or, in any case, more helpless than in the following period. The difference can be described as follows. Until the end of Pius IX's pontificate the Church increasingly used modern means, yet the comprehensive Catholic vision of the world - with all the reservations outlined above was hostile to modernity (whatever that would mean). A historian once

${ }^{37}$ Christopher Clark, 'The New Catholicism and the European Culture Wars', in Culture Wars. Secular-Catholic Conflict in Nineteenth-Century Europe, ed. idem and Wolfram Kaiser, Cambridge, 2003, pp.11-46 (p.45). 
wrote that in his constant criticism of the present Pius IX 'was more a modern leader than he knew' ${ }^{38}$ This expression well reflects the role of modern elements in the Church's policy of the day. They were numerous but governed by a fear of the world. There seem to be no reasons to reject the view, common in earlier historiography, that 'nevertheless, nineteenth-century Catholicism is conservative and on the defensive in its approach to new trends'. ${ }^{39}$ In Leo XIII's times these modern elements became more coordinated, incorporated into one policy of the papacy for the entire Church a policy which aimed no longer to combat modernity as such but to create its alternative model - alternative to enlightened-liberal-secular modernity. In the second half of the nineteenth and the first half of the twentieth century the Church modernized itself by taking over modern institutions, techniques of influence and organizational methods - and directing them against what had hitherto been main strand of modernity. Leo XIII, as we know, encouraged Catholics not to boycott political institutions but to create their own parties, to take part in political life and use it to their own advantage. He sought to resolve the dispute with Bismarck and Germany. Through his encyclical Rerum novarum he sanctioned local forms of social engagement of the Church's people and laid the foundations for modern Catholic social teaching as well as practice based on this teaching. The encyclical Æterni Patris, proclaiming Thomism the Church's official philosophy, had two sides. It can be justifiably said that in the long run, by hampering the development of the Catholic thought along the paths other than Thomism, it prevented a fruitful dialogue - or even a reasonable polemic - with modern science and a majority of new philosophical movements. On the other hand, however, what was positive for the Church in the short run was the very fact that, after the often noted period of decline in the first half of the nineteenth century, theological thought was revived at all - never mind its direction. ${ }^{40}$ Leo XIII's role in opening of Catholicism to the problems of the modern world are unquestionable; in any case, they were opposed by many conservatives at the time and in some monasteries prayers were said asking God to free the Church from this 'Masonic pope'. ${ }^{41}$

${ }^{38}$ Marvin R. O'Connell, 'Ultramontanism and Dupanloup: The Compromise of 1865', Church History, 53, 1984, 2 (June), pp. 200-17 (p. 204).

39 'mimo wszystko jednak katolicyzm XIX wieku ma charakter konserwatywny i zajmuje w stosunku do nowych prądów stanowisko obronne', Karol Górski, Zarys dziejów duchowości w Polsce, Cracow, 1986, p. 274.

${ }^{40}$ Cf. James Hennesey SJ, 'Leo XIII: Intellectualizing the Combat with Modernity', U.S. Catholic Historian, 7, 1988, 4 (Fall), pp. 393-400.

${ }^{41}$ Historia Kościoła, vol. 5, p. 34 (Roger Aubert's phrase). 
The opening had its limitations. Some will be discussed later; here I would like to raise one question immediately evident to all those who compare the history of the Church in the nineteenth century with the earlier periods. As we look at the momentous mental transformations in nineteenth-century Europe, especially in the first half of the century, we must be struck by the fact that 'all this huge ferment [...] was taking place on the margins of the Catholic Church' ${ }^{42}$ I think that this was the first period in the history of Christianity since the Edict of Milan (313) about which something like this can be said. Perhaps for the first time in its history the Church was defending itself, responding to external ideas, unable to define the area under dispute on its own terms. It was quite helpless in its defence, as if forgetting about its great and varied theological tradition, which for centuries had enabled it to absorb and transform very diverse ideological strands to its advantage. A glaring example of this is the Church's attitude to the idea of evolution. It would seem that there should have been no problems with reconciling it with the Catholic doctrine, which, after all, had at its disposal an extremely intricate interpretative apparatus, developed over many centuries, making it possible to reconcile various philosophical and scientific ideas with the Scriptures. It is, therefore, not surprising that for thirty years after the publication of Darwin's main work many Catholic theologians expressed their appreciation for the theory of evolution, seeing nothing in it that would contradict the Church's teaching. It was not until the 1890s that the Holy Office, inspired by a group of conservative Jesuits opposing Leo XIII and associated with La Civiltà Cattolica, condemned the very idea of evolution as incompatible with the Christian truth. This condemnation, which came towards the very end of Leo XIII's pontificate, was a prelude of sorts to an anti-modernist campaign, launched a few years later, in which La Civiltà Cattolica again played an important role. ${ }^{43}$

The Church, scared by modernity, forgot its own tradition; it forgot the basic exegetic rule, formulated already by Origen in the third century CE, whereby the Holy Bible had a corporeal (literal) and an allegorical meaning, and wherever a literal interpretation produced absurd results an allegorical interpretation should be applied..$^{44}$ After all, a literal interpretation of the Bible was not (as its advocates must have thought)

\footnotetext{
${ }^{42}$ Historia Kościoła, vol. 4, p. 260.

${ }^{43}$ Barry Brundell, 'Catholic Church Politics and Evolution Theory, 1894-1902', British Journal for the History of Science, 34, 2001, 1 (March), pp. 81-95.

${ }^{44}$ Étienne Gilson, Historia filozofii chrześcijańskiej w wiekach średnich, Warsaw, 1987 (English original: History of Christian Philosophy in the Middle Ages, Toronto, 1955), p. 37.
} 
a manifestation of Catholic traditionalism but the opposite - a take-over of the idea of Biblical fundamentalism, hitherto associated more with Protestantism. The ramparts of neo-scholasticism may have given people an illusion of security, but, in fact, they cut the Church off from not just modernity, but even from the diversity and multifaceted nature of authentic medieval tradition, in which a whole range of inspiring ideas and views could be found.

An original position was adopted, as in many other matters, by John Henry Newman, perhaps the greatest Catholic thinker of his day. If we assume that the most important intellectual challenges to Christianity in the nineteenth century were posed by scientism, historicism and religious irrationalism (as has been said earlier), they are all central to Newman's reflection. At this point I am interested in the problem of historicism. In his Essay on the Development of Christian Doctrine (1845) Newman sought to demonstrate that the idea of the continuity of the Christian doctrine since the Apostolic times until the present did not preclude its evolutionary transformations. Thus the idea of the continuity of the Christian doctrine could be reconciled with historicism, which dominated the nineteenth-century humanities. Important in the context of the dispute over evolution was the fact that Newman put himself among the "pioneers of modern thinking in terms of development $^{\prime 45}$ - along with Darwin, Spencer and several other thinkers. Therefore, it comes as no surprise that Newman found nothing scandalous or anti-religious in Darwin's theory of evolution - after all God's omnipotence will not be undermined, if we assume that creation occurs indirectly and gradually, through a process of evolution, which in itself is God's creation. ${ }^{46}$ However, Newman's solution was not appreciated in the Church of his day. Perhaps an even bigger intellectual failure was the inability to use the potential of an early twentieth-century movement known as Catholic modernism. Its very strong condemnation, without any attempt to make a distinction between its various elements, affected thinkers venturing beyond Catholicism just as much as those for whom 'Catholic dogma [...] was an insurmountable

${ }^{45}$ Witold Ostrowski, 'Książka z Littlemore' [introduction], in John Henry Newman, O rozwoju doktryny chrześcijańskiej, Warsaw, 1957, pp. 5-18 (p. 12).

${ }^{46}$ Newman expressed his views on Darwin's theory in a letter to Canon J. Walker of 22 May 1868, in The Letters and Diaries of John Henry Newman, 32 vols, London and Oxford, 1961-2008, vol. 24: A Grammar of Assent: January 1868 to December 1869, ed. Charles Stephen Dessain and Thomas Gornall, Oxford, 1973, pp. 77-78, available online on Interdisciplinary Encyclopedia of Religion and Science 〈http://inters.org/Newman-Scarborough-Darwin -Evolution $>$ [accessed 15 October 2015]. 
barrier', ${ }^{47}$ creating a gap between twentieth-century thought and the Church that seemed unbridgeable. ${ }^{48}$

Thus the opening to the modern world was limited, but even if limited so much (perhaps because it was limited so much?), the opening had its price. By building its modern image of the world against the dominant model of rational-liberal-enlightened modernity, the Church made a political choice and thus, whether it wanted or not, became one of the political parties. When the Church became involved in the Christian social movement, this party-like nature became even more pronounced. This assertion can obviously be questioned. Had the Church not always defined itself with regard to its enemies? Was such an attitude not on the rise during the Reformation and Counter-Reformation? It probably was, but it became particularly pronounced in the Enlightenment period and, especially, in the times of Pius IX, given the fact that the Church deliberately dissociated itself from various strands of modernity. And when it began, carefully and selectively, to open itself to modernity, this "party-like' nature of the Church did not disappear but grew even stronger. The party-like nature of the Church was, in a way, a price for its social activism - as long as it remained passive, it was not visible. Brian Porter-Szücs (whose book about the attitude of the Church to the Polish national idea in the late nineteenth and first half of the twentieth century has been one of the most important inspirations for me) points to the transformation in the understanding of the concept of struggle in the Church. We can discern in this transformation an influence of the idea of social Darwinism, generally rejected by the Church. The Church had always called for a fight against external enemies, always stressing, however, that the most important front of the spiritual fight was to be found in the soul of each believer: we are all involved (to quote the great Polish Baroque poet Mikołaj Sęp-Szarzyński) in a 'mortal combat [...] against Satan, the world and the flesh' (with the 'world' in this phrase being understood as temptations leading us to evil). Now the fight became a fight against hostile political parties: the enemy was had become externalized. In the theological sphere this signified a 'deindividualization' of Catholicism: collective attitudes became more important as a pastoral theme and focus of

\footnotetext{
47 Zygmunt Zieliński, Papiestwo i papieże dwóch ostatnich wieków, 2nd edn amended, 2 vols, Poznań, 1986, vol. 2, p. 36.

${ }^{48}$ The three most important books for me about Catholic modernism: Claus Arnold, Mała historia modernizmu, Cracow, 2009 (German original: Kleine Geschichte des Modernismus, Freiburg, Basel and Vienna, 2007); Marvin R. O'Connell, Critics on Trial. An Introduction to the Catholic Modernist Crisis, Washington, DC, 1994; Marian Zdziechowski, Pesymizm, romantyzm a podstawy chrześcijaństwa, 2 vols, Cracow, 1914.
} 
the clergy's attention than individual experiences. ${ }^{49}$ In analysing the process with reference to Polish Catholicism, Porter-Szücs is right in noting that this was in a way the reverse of the emergence of the Church's social teaching. The Church became greatly interested in social problems, noticed the enormousness of workers' misery and looked for remedies - by doing so, it built its social programme, but at the same time it followed the logic of the functioning of a political party with all its consequences. Such an attitude may have also been partly a result of a greater than ever pluralism of religious and political life: when the principle of cuius regio, eius religio was in force, heretics remained on the margins of society and so preachers had to focus not on them but on individual sins of the believers. Now the wolves became almost indistinguishable from the sheep.

However, the price of social engagement was even higher. One of the most fascinating phenomena was a change in the Church's attitude to nationalism. The change was - without a doubt - a form of modernization of the Church. Let us look at the entry nationality in Encyklopedia katolicka (Catholic Encyclopaedia) edited by Father Michał Nowodworski. We can read there - as if in the spirit of Herder - that 'individual traits as marks of nationality, like the differences between human beings, are the work of Divine Providence and part of the plan of the universe; for the variety of national characters allows humankind to fulfil its task comprehensively; each nation applies itself to its fulfilment as its qualities and talent allow. Such is in this respect the intention of Divine wisdom.' The 'unity of humankind' exists above any differences between peoples and races. 'All people were created in the image and likeness of God, all have the same spiritual and physical strengths, all have one goal set before them, which they are to pursue under the guidance of Divine Providence. All people belong to one huge family whose lord and lawmaker is God. [...] National pride is as much reprehensible as pride in private life.' There are nations and there are states, the 'right to exist' for both is 'enshrined in God's law'. 'Thus God's will is violated by those who in the name of nationality undermine and overthrow state associations, existing by force of the law of history, as well as those who, on behalf of the state and alleged state interests, oppress nationality and seek to exterminate it.' The idea is clear: nationalities have the right to exist, they have to be tolerated by the state authorities, but have no right to build nation states. Unfortunately, today the world is ruled by "liberalism with its materialistic aspirations. It is the father of the modern "nationality principle", which, in complete contradiction to the

${ }^{49}$ Brian Porter-Szűcs, Faith and Fatherland. Catholicism, Modernity and Poland, New York, 2011, pp. 232-72. 
Christian idea of nationality, has already brought so many disasters upon Europe. Exponents of this doctrine' believe that 'national and state bodies should overlap completely'. Just as selfishness is apparently the driving force behind actions of individuals, egoism - those of peoples, which gives rise to hatred. 'By closing each nationality in itself, it [the nationality principle in its liberal sense - M.J.] must be seeking to break the unity of the Church'. ${ }^{50}$

Thirty years passed. In April 1913 Polish bishops from Galicia sent an open letter to the press concerning the electoral reform prepared by the Cracow conservatives (primarily the then viceroy of Galicia, Michał Bobrzyński). ${ }^{51}$ The letter was signed by Archbishops of Lwów of the Latin rite (Józef Bilczewski) and the Armenian rite (Józef Teodorowicz) as well as bishops of the Latin rite: of Cracow (Adam Sapieha), Przemyśl (Józef Pelczar) and Tarnów (Leon Wałęga). Work on the reform had been going on in Galicia for many years ${ }^{52}$ and the bishops expressed their opposition just before its finalization. This is no place for a detailed analysis of the entire affair; by opposing the reform, the bishops sided unequivocal-

50 'indywidualne cechy, znamionujące narodowość, tak samo jak odmienności jednostek ludzkich, są dziełem Opatrzności boskiej, wchodzącym do planu wszechświata; gdyż rozmaitość charakterów narodowych pozwala rodzajowi ludzkiemu wszechstronnie spełnić postawione mu zadanie; każdy lud przykłada się do jego spełnienia odpowiednio do swoich właściwości i swego uzdolnienia. Taki też jest pod tym względem zamiar mądrości Boskiej. [...] Wszyscy ludzie stworzeni na obraz i podobieństwo Boga, wszyscy posiadają takież same siły duchowe i fizyczne, wszystkim wytknięty został cel jeden, do którego dążyć mają pod kierownictwem Opatrzności boskiej. Wszyscy ludzie są członkami jednej olbrzymiej rodziny, której panem i prawodawcą jest Bóg. [...] Pycha narodowa jest tak samo potępienia godną, jak pycha w życiu prywatnym. [...]. Wolę Bożą gwałci więc ten, kto w imię narodowości podkopuje i obala związki państwowe, istniejące mocą prawa historycznego, jak również ten, kto w imieniu państwa i mniemanych interesów państwowych gnębi i wytępić usiłuje narodowość; "liberalizm, ze swymi materialistowskimi dążeniami. On to jest ojcem nowoczesnej "zasady narodowości”, która pozostając w zupełnej sprzeczności z chrześcijańskim pojmowaniem narodowości, tyle już klęsk sprowadziła na Europę. Stronnicy tej doktryny' believe that 'narodowe i państwowe organizmy powinny się wzajemnie zupełnie pokrywać'. 'Zamykając każdą narodowość w sobie samej, musi ona [the nationality principle in its liberal sense - M.J.] pracować nad rozerwaniem jedności Kościoła'. J. N. [Jan Nowodworski], 'Narodowość', in Encyklopedia kościelna podług teologicznej encyklopedii Wetzera $i$ Weltego z licznymi jej dopetnieniami, ed. Rev. Michał Nowodworski, 33 vols, Warsaw, 1873-1933, vol. 15, 1883, pp. 548-58.

51 'Pismo XX Biskupów polskich', Czas, 66, 17 April 1913, no. 177, afternoon edition, p. 1.

${ }^{52}$ The only comprehensive monograph is still Józef Buszko's book Sejmowa reforma wyborcza w Galicji, 1905-1914, Warsaw, 1956. Valuable when it comes to facts, interpretatively it is, unfortunately, heavily influenced by the period in which it originated. The general principles of the reform presented there, pp. 226-29. 
ly with the National Democrats against the Cracow conservatives. It was a revolution in Polish politics, a revolution the significance of which may still be underappreciated in Polish historiography. National Democracy replaced traditional conservatism and began to dominate the right wing of the Polish political scene.

It is evident that something very important happened in Catholic thought in the quarter of a century preceding the First World War. The transformation was slow and gradual, with a considerable part of the phraseology preserved, so much so that for some - both the authors and the addressees - it may have gone unnoticed. The language of protest against radicalism is equally strong in the entry from Encyklopedia katolicka and in the letter by the Galician bishops; both the encyclopaedic entry and the bishops' letter express concern over the fact that nationalism divides Christians, the only difference being that the sense of the former lies in the Church distancing itself from the nationalist movement, while that of the latter - in the support for the movement in question.

However, there is also a significant difference in the phraseology. The Galician Church, as Porter-Szücs strongly emphasizes, was really moved by the ideas of Rerum novarum..$^{53}$ The signatories of the letter, especially bishops Pelczar and Bilczewski, were among the most zealous advocates of the new social engagement. The ideas of social justice and democratization, so clearly (particularly in the case of the latter) present in the bishops' document, were a clear sign of a new understanding of the Church's role in the world. Nationalism is not overtly proclaimed in the letter, yet it does constitute its ideological foundation. The essence of the profound and subtle art of national compromises in Austria-Hungary, those achieved and those (more numerous) merely attempted, was to balance the political system in such a way so as to avoid any of the nationalities in this multiethnic region being overwhelmed by the other nationalities. This was to be achieved by national curias in representative institutions as well as a division of constituencies between the nationalities to ensure representation for each of them. This is what the bishops spoke against above all. The argumentation was purely nationalistic: designing constituencies in a way that ensured representation for various nationalities (including, as the bishops put it, 'non-Christian population', which in the Galician context must have denoted Jews) meant that those Poles who would remain outside the constituencies allocated to Poles were lost to the "Christian population' (that is, their votes would be 'wasted' during the election).

53 Porter-Szűcs, Faith and Fatherland, pp. 125, 130-132. 
Declaring their friendliness towards the 'Ruthenian' people and the 'brotherly' Greek Catholic rite, the bishops expressed their opposition to separate constituencies for Poles and Ukrainians. Thus they destroyed the very sense of the reform - an attempt at a Polish-Ukrainian compromise, as the lack of such a division favoured the stronger nationality, that is the Poles. Thus without saying it directly, they adopted a stance close to that of the National Democracy.

Strongly in favour of democratization, the bishops explained the motives behind such an attitude: Polish peasants were full of respect for the Church, they were a stronghold of faith and nationality, they were the main force opposing the Kulturkampf in the part of Poland annexed by Prussia. Yet in order for Polish society to be able to express its true soul (precisely the one presented above), it had to be free from the radicalism manifested in the planned electoral reform. The letter does not say wherein lay the radicalism of the electoral reform. We do know from other sources that a role in this was played by an anti-clerical left-wing peasant activist, Jan Stapiński, who at that time supported the conservative Stańczyk group against the National Democrats - though it seems that a more general matter was at stake here. The Church found it easier (albeit without enthusiasm) to come to terms with democratization (that is, the increasing influence of the masses on political life) than with liberalism understood as individual liberty, both with regard to actions and conscience. As long as the majority of society was Catholic in one way or another, democracy made it possible to maintain the Church's domination; on the other hand, a system with built-in mechanisms to protect minorities (and this was what a compromise among nationalities must have been about) provoked dislike and distrust among bishops: it atomized, it introduced discord, to some extent it also enabled individuals to engage in non-conformist behaviour, and was, therefore, a manifestation of the dangerous radicalism.

Although the letter in question does not contain any antisemitic declarations, they do appear in a polemical text by one of the signatories, the Armenian archbishop Teodorowicz, who in his views was probably the closest to National Democracy among the five signatories (and who, as Waldemar Łazuga writes, was the driving force behind the letter). ${ }^{54}$ In 1916 Bobrzyński published, anonymously, a brochure entitled Dialog o zasadach $i$ kompromisach (A Dialogue on Principles and Compromises), defending the policy behind the 1913 electoral reform. Teodorowicz responded

${ }^{54}$ Waldemar Łazuga, Michał Bobrzyński. Myśl historyczna a działalność polityczna, Warsaw, 1982, p. 166. 
with a polemical brochure (also published anonymously), ${ }^{55}$ in which he explained the motives behind the opposition to the planned reform. For example, Bobrzyński defended the policy of integrating Jews with Poles, in response to which Teodorowicz accused him of cynically using the Jews against the Poles in his policy and compared such an attitude to the old nobility using the Jews to oppress peasants through the alcohol monopoly on their estates, calle propinacja. All this, however, does not fully explain the mechanism behind the shift of support from the Stańczyk group to the National Democrats. After all, the electoral reform against which the Galician bishops protested was not the work of radical revolutionaries, but of Cracow conservatives, who had ruled the province for nearly half a century and regarded themselves almost as ex officio defenders of the faith and the Church. We can imagine the shock and confusion within the Stańczyk group. The intellectual leader of the group, Count Stanisław Tarnowski must have been very offended indeed, when he heard the gossip, circulated in Galicia, that Archbishop Teodorowicz described him, in a private conversation, as the most dangerous enemy of the Church. ${ }^{56}$ The eminent medievalist Stanisław Smolka wrote that for 913 years, since the beginning of the Polish episcopate, there had been no 'equally harmful' step taken by the bishops. ${ }^{57}$ On the other hand, National Democracy was still surrounded at the time by an aura of a radical movement; its militant Antisemitism (which had reached its peak several months earlier during the campaign before parliamentary elections in the Kingdom of Poland, in the autumn of 1912) continued to shock many, both on the right and on the left. The elements of racism and social Darwinism, present in its doctrine, should have put the clergy off, while most of its leaders, including Roman Dmowski, brought up in an atmosphere of positivism, had no religious sympathies whatsoever. The bishops' attitude must have been, therefore, surprising.

The history of the evolution in the Galician bishops' attitudes, obviously marginal from the point of view of the universal Church, is a perfect example of how the Church responded to modernizing changes in the late nineteenth and early twentieth century. What was at work -

55 [Józef Teodorowicz], Stańczyk bez teki. Odpowiedź na 'Dialog o zasadach i kompromisach', Warsaw, 1917.

${ }^{56}$ Bobrzyński learned about this opinion by Teodorowicz from Władysław Leopold Jaworski in a letter of 17 December 1913, quoted in Buszko, Sejmowa reforma wyborcza w Galicji, p. 256.

57 Stanisław Smolka's letter to Michał Bobrzyński, 24 April 1913, quoted after Łazuga, Michał Bobrzyński, p. 166. 
I believe - was the following mechanism: the Church's social work prompted by the new needs emerging as a result of great socio-economic transformations lasted throughout the nineteenth century until it was finally sanctioned and incorporated into the very heart of the Church's teaching through the encyclical Rerum novarum. In pastoral practice this social engagement clashed with the social engagement of the social democratic movement as well as liberal enlightened modernization, with the clash being facilitated by the increasingly common adoption of the political party formula by Christian social movements. After all, political parties thrive on conflicts with other parties. It became necessary for the Catholic movement to present itself as clearly different from other (usually more left leaning) forms of social engagement. In this situation at the turn of the twentieth century the Catholic social movement drifted towards nationalism and modern Antisemitism by the very force of inertia. Traditional anti-Jewish prejudice had 'always' been present in the Church, of course, and antisemitic ideas could be found in various Catholic milieus (as probably everywhere else in Europe at the time), yet now we were dealing with something new - an antisemitic social movement emerging in local Catholic circles, often against the resistance of the traditional hierarchy. The Christian social movement in Austria or the work of Father Stanisław Stojałowski in Galicia are good examples here. The antisemitic or nationalistic element was often combined with genuine social engagement (like in Stojałowski's case); anyway, often one aspect could not be separated from the other. The socialization of Catholicism (and probably Protestantism as well) meant at the turn of the twentieth century that in most cases it became increasingly susceptible to more or less radical nationalistic slogans.

As long as the Church remained largely indifferent to social issues, it could loftily distance itself from modern nationalism and modern radical Antisemitism, regarded with reserve as plebeian movements. Yet the moment the Church decided that it could not remain silent on social issues, that the voice of the masses should be taken into account to a greater extent, it became difficult to avoid nationalistic engagement. I do not want to pass judgements. Rerum novarum was epoch-making and, given the mental situation at the time, avoidance of strong nationalistic and antisemitic influences was very unlikely. Nevertheless, the effect was that the Church managed to stop Dechristianization at the price of moving towards the nationalistic right. As Ilona Zaleska's research has demonstrated, in the early twentieth century probably the only Catholic milieu in Poland strongly opposing the nationalism of National Democracy was precisely the most conservative, thoroughly anti-modernist milieu, 
associated with the Częstochowa-based journal Myśl Katolicka (Catholic Thought). The same group criticized Archbishop Teodorowicz as an advocate of liberal Catholicism ${ }^{58}$ and attacked 'this strand of degenerate love for the fatherland [...] known as extreme nationalism,' which 'has its source in the paganization of our societies'. ${ }^{59}$ It is clear that in its attitude to nationalism Myśl Katolicka stopped at the entry from Encyklopedia katolicka quoted above, which equated nationalism, liberalism and Dechristianization. Something else is clear as well: Catholics were unable to criticize (or, in any case, found it extremely difficult to criticize) the nationalism of National Democracy from positions other than ultra-traditional ones. More and more modern Catholics CE 1910 were becoming nationalists.

In Poland's case there is also the fascinating question of the theology of the nation. The idea itself was not new, it could draw on medieval, Baroque and later models; in Poland - on Jan Paweł Woronicz's early nineteenth-century poetry as well as the ideas of Romantic messianism, heterodox and rejected by the Church, but very influential in Polish culture. Now, however, there began to emerge a coherent theological thought according a 'baptized nation' as a whole a special ontological status and a special place in God's plans. It would be fully expounded by Cardinal Stefan Wyszyński's in communist times.

It is of great importance to the subject matter of this article that this turn to the right, to nationalism and Antisemitism, was not a form of the Church's departure from modernity, a compromise with tradition and pre-modern forms of social life and so on. On the contrary - it was a form of modernization of Catholicism, the Church's adaptation to the requirements of modern politics in an era of mass political parties. When compared with the Catholicism of the previous generations, this support for nationalism was a revolutionary change.$^{60}$ It constituted an aspect of the phenomenon referred to earlier: modernization through the creation of a model of modernity alternative to liberal-enlightened modernity.

Why exactly did the modernization of the Church go in that direction? I dare to pose a fundamental question: why did the Church fail to support the main strand of nineteenth-century modernity, that is the enlightened-liberal strand? After all, a revolutionary transformation through adaptation to modernity had already been embarked upon;

${ }^{58}$ Ilona Zaleska, Kościół a Narodowa Demokracja w Królestwie Polskim do wybuchu I wojny światowej, Warsaw, 2014, p. 333.

59 'Odsłoniły się karty’, Myśl Katolicka, 23 June 1908, no. 16, quoted after Zaleska, Kościót a Narodowa Demokracja, p. 340.

${ }^{60}$ Cf. Porter-Szücs, Faith and Fatherland, pp. 206-07. 
the take-over of social issues and rapprochement with the modern right was no less radical a break with tradition than any acceptance of the ideals of the Enlightenment.

All the more so given the fact that the Enlightenment - as research from the last few decades has demonstrated beyond any doubt - was far less anti-religious than is stereotypically thought. I have already mentioned the German Christian Enlightenment, but this applies to other countries as well. Even the French Revolution was not initially directed against the Church. The simplest answer to the above question could be: 'because the Enlightenment came first' ${ }^{61}$ Since the Church turned against the tradition of the Enlightenment already in the eighteenth century, then automatically, as it were, it became close to anti-Enlightenment strands - right-wing and nationalistic - over the course of the following century. It did not turn against the new nationalism, because the position of the 'chief villain' had already been taken. There was another factor at play, the impact of the French Revolution: terror, followed by the humiliation of the papacy by Napoleon pushed the Church away from the Enlightenment. I believe, contrary to what textbooks suggest, that the revolution did not strengthened, but weakened the European impact of the ideas of the Enlightenment. This applies to the change in the attitude of both monarchs and the elites (rejecting enlightened absolutism and reformist ideals in favour of rigid conservatism), and the Church. As a result of the revolution, the Enlightenment began to be seen ex post through the perspective of the French Enlightenment, perceived one-sidedly, as a radically anti-Christian strand of thought leading inevitably to terror and a radical social revolution. The Church wished to have nothing in common with such an Enlightenment.

And yet throughout the nineteenth century there existed another movement - sometimes getting weaker, sometimes stronger - Catholic liberalism. Catholic liberals suggested a modernization of the Church that would not be an 'alternative modernization' but one that would 'draw the Church' into the main stream of post-Enlightenment changes through the Church adopting the fundamental Enlightenment paradigm in its Catholic version. One of the most outstanding exponents of this movement, Count Charles de Montalembert, tried to show his fellow believers the advantages of political liberty and a parliamentary-constitutional system. He stressed that the first half of the nineteenth century was a period in which Catholicism flourished in conditions of religious liberty. Like all Catholic liberals, he gave as his prime example Belgium, where a liberal political system was

${ }^{61}$ This idea was suggested to me in a conversation by Maciej Górny. 
combined with an unprecedented growth of the Church. At the same time support for liberty was not motivated by tactical considerations, but by the general recognition that 'liberty is one of the vital powers of humanity', while 'religion is its safeguard'. ${ }^{62}$ If the liberals made a mistake in attacking religion and denying the existence of a supernatural order, then the Catholics responded with an analogous mistake, rejecting liberty. Montalembert warned against the Church's involvement on the side of despotic monarchs: 'But of all despotisms, the most intolerable to the nations of our days is that which is exercised, or seems to be exercised, with the sanction of religion. It calls into rebellion the noblest sentiments of our souls, because we feel that it is the exercising of that which is sacred for the advantage of a profane interest' ${ }^{63}$

On the other hand Catholic conservatives believed, like some anti-clerical radicals, that Catholic liberals, even if subjectively acting in good faith, were undermining the Church, because the objective process of rationalization of the world undermined religion. There is an inherently pessimistic assumption in this on the part of Catholic conservatives - not only metaphysically pessimistic, that it is impossible to achieve perfection because of the original sin, but also historiosophically pessimistic, that time and progress favour anti-clerical secularists. It would seem that in this case Catholic traditionalists took over the belief of the people of the Enlightenment in the progress of the mind and turned it upside down. The most popular anti-liberal Catholic polemicist, Louis Veuillot, as if entering into a polemic with the above quote by Montalembert, rejected all claims to liberty and very firmly presented a concept of a monarchic state in which moral norms, defined by the Church, were imposed by the law. There is no freedom and there can be no freedom in the sense of tolerance for erroneous opinions and behaviours: 'There is no such thing as human freedom in this perilous sense; God has not made weak creatures a present of this dangerous gift. God alone is free. To us He has given, not freedom, but free will'. ${ }^{64}$

62 'la liberté est une des forces vitales de l'humanité', 'la religion est sa sauvegarde', Charles de Montalembert, Des intérêts catholiques au XIXe siècle, Brussels, 1852, p. 27, English translation, Catholic Interests in the Nineteenth Century, London, 1852, p. 72.

${ }^{63}$ 'De tous les despotismes, le plus intolérable aux nations de nos jours est celui qui s'exerce ou semble s'exercer avec le concours de la religion. Il soulève les meilleurs sentiments de notre âme, parce qu'on y sent l'exploitation d'une chose sainte au profit d'un intérêt profane', ibid., pp. 107-08. English translation, pp. 72-73.

64 'Non, il n'y a point de liberté humaine dans ce sens périlleux; Dieu n'a point fait ce dangereux présent à des êtres faillibles. Dieu seul est libre. Il nous a donné le libre arbitre, point la liberté', Louis Veuillot, L'illusion libérale, 5th edn, Paris, 1866, p. 50. English translation, The Liberal Illusion, Washington, DC, 1939, p. 40. 
The complicated power struggle between conservative and liberal Catholics can be seen perfectly in the disputes surrounding the Syllabus. The best known, textbook-like manifestation of the power of traditional Catholicism of Pius IX's times is the Syllabus of Errors, published by the pope in 1865 as an annex to the Quanta cura encyclical. Its eighty points made up a list of views condemned by the pope (and therefore each of its assertions was preceded by an implied phrase of 'it is not true that'). It became a favourite document for both the ultramontanes and the anti-clericals: the former saw in it a triumph of true faith, the latter - evidence of the anachronistic nature of the papacy and its intellectual decline. In fact, the matter was far more interesting and far more complicated.

A few months later, the Archbishop of Orléans, Félix Dupanloup, a well-known polemicist regarded as a sympathizer of liberal Catholics, published a book defending the Syllabus against anti-clerical attacks. In its first part Dupanloup sharply criticized the convention between France and Piedmont, in which Napoleon III for the first time admitted the possibility of Rome being handed over to united Italy. More important to us here is part two, containing a detailed analysis of the Syllabus. Armed with a method of Biblical exegesis enshrined in centuries-long tradition, Dupanloup carries out a meticulous analysis of the various points of the Syllabus to demonstrate that the attacks by the anti-clericals are groundless. His central argument derives from formal logic: if the Syllabus points are in the form of negation (it is not true that... and so on), a true proposition is not the one contrary to the negated proposition, but a negation of the negation (a negation of the proposition 'not q' is not ' $q$ ', but 'there is at least one case that q'): if in the Syllabus the pope condemns the view that people have a right not to listen to their legal authority, this does not signify that people always have to listen to the authority, but that there are cases when people must listen to it. ${ }^{65}$ The same applies to the pope's condemnation of the view that states should not interfere in the internal affairs of other states. After all, the pope cannot mean that intervention is always acceptable, because that would be absurd. He means that there are situations when an intervention is acceptable - and such a proposition is hardly controversial. In this last case Dupanloup - in line with Cardinal Giacomo Antonelli's letter mentioned below - also refers to the context of the entirety of papal pronouncements listed in the Syllabus, which made it possible to demonstrate that the condemnations, which are in the form of general statements in the Syllabus, referred, in fact, only to

${ }^{65}$ Félix Dupanloup, La Convention du 15 Septembre et l'encyclique du 8 Décembre, Paris, 1865, p. 101. 
some specific situations. The most difficult was the well-known proposition that the pope 'ought to reconcile himself and come to terms with modern civilization'. Yet, as Dupanloup writes, it is impossible to 'reconcile oneself' or 'not reconcile oneself' with what is good, because good things are simply accepted and that is that. What the pope meant was that he could not come to terms with the negative aspects of modern civilization, but very much approved of its positive aspects. ${ }^{66}$ Finally, when the pope criticizes 'modern liberalism', Dupanloup explains: the adjective 'modern' is limiting. If the pope used it, then evidently he wanted to stress that he condemned only a specific variety of liberalism, namely modern liberalism, not liberalism as such. This is followed by a historical argument aimed at demonstrating that the Church has always been in favour of liberty - thus accusing it of hostility to liberalism is evidence of ignorance and extreme anti-clerical bias. ${ }^{67}$

Dupanloup's book is a major challenge to a historian. On the one hand, his argumentation draws on hermeneutic principles present in Catholic exegesis for centuries (although, as has been mentioned earlier, marginalized in the nineteenth century). In theology 'it is necessary to distinguish a lot in order not to confuse a lot. Truth has infinite nuances and it is necessary to know how to discern these nuances and not mix them' ${ }^{68}$ Dupanloup is undoubtedly right in stressing that the Syllabus points often concern very specific, not general matters, that condemnation of some propositions as false does not mean that propositions to the contrary are true. Pius IX sent Dupanloup a letter expressing his gratitude for his defence against attacks by enemies of the Church - the Archbishop of Orléans would from now on print the letter at the beginning of his book as immunization of sorts against possible criticism. It might also be added that the Syllabus was not addressed to all the faithful, but just to the bishops, and was not part of Quanta cura, but was just sent to the bishops together with the encyclical. It was prepared, as we can learn from a letter by the Secretary of State, Cardinal Antonelli, attached to it, as a kind of list of papal statements on modernity: each point was an abbreviated quote from a papal pronouncement with a reference to the entire pronouncement. As Antonelli reminded the addressees of the Syllabus, each point could be understood only in the context of the entire pronouncement in question, never just in itself. On the other

${ }^{66}$ Ibid., p. 104.

${ }^{67}$ Ibid., pp. 115-18.

68 'il faut beaucoup distinguer, sous peine de beaucoup confondre. La vérité a des nuances infinies, et il faut savoir discerner ces nuances, ou ne pas s'en mêler', ibid., p. 106. 
hand, we migh task, 'So what?'. The Syllabus reached the readers - the faithful and the rest - in the form we know it today, a list of condemned propositions, without any explanations or additions. The Holy See never distanced itself from the reception of the Syllabus criticized by Bishop Dupanloup.

The American historian Marvin R. O'Connell (from whose article I found out about the whole story) proposes an intriguing interpretation. In his view Dupanloup's book is only seemingly a polemic with the anticlericals; in fact, its main addressees are Catholic traditionalists and it is in the context of the dispute between the two movements within the Church that the book should be interpreted. We are dealing here with an implicit (though never explicitly pronounced) compromise which underpinned, in fact, the entire functioning of the liberal and conservative wings in the Church for one hundred years between Pius IX's pontificate and the Second Vatican Council (perhaps we should add 'and later'?). The compromise was based on the fact that Catholic traditionalists managed to persuade Rome to issue very conservative documents, while Catholic liberals later presented an interpretation of the documents that made them considerably less severe. Rome did not side clearly with any of the sides in order not to fuel the dispute. This maintained the fragile equilibrium between the two wings. The situation was the same, according to O'Connell, with the dogma of papal infallibility. In 1865 Newman predicted that papal infallibility, if it was going to be officially proclaimed, would have so many restrictions 'that it will leave things as they are ${ }^{69}{ }^{69}$ And this is what indeed happened.

I think that O'Connell's interpretation is correct. In the early twentieth century even the very principled condemnation of Catholic modernism in the encyclical Pascendi dominici gregis (1907), which seemingly left no room for a compromise, could to some extent be disarmed in a similar manner. A letter by the German episcopate of January 1908 expressed joy at the fact that 'the system [...] condemned in the encyclical [...] does not seem to be defended by any clergyman or any layman in Germany'. The German historian from whose book the quote comes is right in his comment that such an interpretation turns the main idea of the encyclical upside down, the idea which clearly says that its goal is to expose the principles the modernists themselves do not acknowledge for tactical reasons. ${ }^{70}$

Such a compromise obviously satisfied neither the traditionalists, like Veuillot, nor very highly principled (an unkind historian could say

${ }^{69}$ O'Connell, 'Ultramontanism and Dupanloup', p. 217.

${ }^{70}$ Arnold, Mała historia modernizmu, pp. 117-18. 
slightly doctrinaire $)^{71}$ Catholic liberals like Lord Acton, who strongly criticized Dupanloup and Newman for their attitude, which he considered to be opportunistic. Acton opposed what in his view was a false concern for the 'good of the Church', which prompted people to hide the truth or fight ideas that could harm the Church. He pointed out that while on the theological level there was a clear division between the truths of faiths and recommendations not binding on the Catholics in their conscience, in its pastoral practice the Church sought to blur this difference and present various instructions as truths of faith. Nevertheless, the compromise discussed here made it possible to preserve the liberal strand in the Church. Irrespective of whether we agree with this strand or not, its very existence kept the debates going and raised the intellectual level of the Catholic thought - and thus was an important factor opposing Dechristianization.

The most difficult part of the study will be an attempt at a conclusion. In every historical period we find opposing tendencies. Often they are nearly equally strong and the ultimate victory may be decided by a marginal advantage. Often the victory is determined by us, historians, when, looking ex post, we grant one tendency an advantage over another, introducing an illusory order into the chaos of events, an order which, in fact, exists only in our minds. Aware of this danger, I will venture to say that, on the whole, we cannot speak of a Dechristianization of Europe in the nineteenth century. To quote Berger again, modernity pluralizes - various figures suggest, on the one hand, masses of people from Western European cities abandoning religious services and sacraments, and on the other - often at the same time and in the same countries - an increase in priestly and monastic vocations. There emerged, as has been said, more and more groups in which non-belief was the norm and, on the other hand, state schools, viewed with such reluctance by the Church, disseminated among the masses - thanks to mandatory religion classes - religious knowledge on a scale that may have been greater than ever before. The influence of Christianity in many spheres was on the wane, but in others it grew stronger - there was no mass departure from religion. In this sense the nineteenth century was not a harbinger of things to come in the second half on the twentieth

${ }^{71}$ Cf. primarily Gertrude Himmelfarb, Lord Acton, Chicago, 1952, as well as (as a polemic): Terrence Murphy, 'Lord Acton and the Question of Moral Judgments in History: The Development of His Position', Catholic Historical Review, 70, 1984, 2 (April), pp. 225-50 〈http://www.jstor.org/stable/25021806〉 [accessed 12 June 2015]. 
century. ${ }^{72}$ It is a different matter whether the nineteenth-century transformations marked the beginning of processes that led to a considerable weakening of Christianity in Europe in the second half of the twentieth century; in such a case it is possible to speak of Dechristianization phenomena in the previous century, but this would mean they were a time bomb. However, such an assertion seems to me extremely hard to prove or disprove and perhaps it belongs more to the sphere of historiosophy rather than historical research. In any case, it goes beyond the chronological framework of the present study.

I am inclined to agree with Berger ${ }^{73}$ that the theory of secularization is of little help in understanding historical phenomena - even if it is not unequivocally erroneous, it is hugely one-sided. Notwithstanding the lack of clarity in the term itself (what term is clear in the humanities?), it takes some phenomena out of their context. One scholar has noted, for example, that when analysing the decline of religious practices in the twentieth century, we need to take into account the fact that the century was in general a century of declining participation in all social institutions - parties, clubs, associations or unions. Thus the declining participation in religious associations, wherever it occurred, was part of a broader trend and not a separate phenomenon. ${ }^{74}$ If the theory of secularization is acceptable, it is so only if we understood secularization in a narrower sense, as a separation between the state and the religious sphere. (This is how secularization is understood by the editors of the book on secularization in Czech-speaking regions in the nineteenth century quoted earlier). The existence of such secularization in the age of steam and electricity is beyond doubt, but it has nothing to do with the problem of a growth or decline in the intensity of religious life - thus, when it comes to the subject matter of this study, we remain at the starting point.

On the other hand, when it comes to the popular linking of secularization to a rise in rationalism, in my opinion the matter can be presented as follows: in the literal sense this assertion is certainly false. There is no evidence to suggest that people today behave more rationally than ever before. An aphorism misattributed to Gilbert K. Chesterton (but accurately

72 As is very strongly stressed by Nipperdey, Deutsche Geschichte, p. 403.

${ }^{73}$ Berger, 'Secularization Falsified'. It should be stressed that in his more recent works Berger sees this question differently than in his most important book on the sociology of religion written fifty years ago, The Sacred Canopy (1967), in which he was inclined to accept the theory of secularization.

${ }^{74}$ Jonathan C. D. Clark, 'Secularization and Modernization: The Failure of a Grand Narrative', Historical Journal, 55, 2012, 1, pp. 161-94 (p. 164). 
summing up his views) hits the nail on the head, I think: 'When a man stops believing in God he doesn't then believe in nothing, he believes anything' ${ }^{75}$ Perhaps Dechristianization, if it does occur, results from a weakening rather than strengthening of rationalism: mass culture abandons religion not because the public at large becomes increasingly rational, but, on the contrary, because religion with its sophisticated theological system, philosophical problems and so on, is more difficult to accept than the belief in flying saucers or - to stick to the nineteenth century - occultism. In this sense Max Weber was mistaken: there is no disenchantment of the world in the modern era. When it comes to individual attitudes, the matter seems obvious to me.

Yet the concept of progressing rationalization cannot hold on the level of social institutions either. Weber believed that the bureaucratic system of Western modern states was in some way more rational than other social systems; I think that there are no grounds for such an opinion. ${ }^{76}$

If the disenchantment thesis were to hold, it would be only on the psychological, not philosophical level. It can be argued as follows: people today believe themselves to be rational; they speak of reason as the highest authority, which by no means translates into rationality in their behaviour. This interpretation is worth considering, but then we would be faced with a situation in which the myth of rationalism and not rationalism itself replaces religion.

Durkheim thought that there would always be room for religion not this or that religion but religion as such - in human culture, and justified this idea in the following manner: even assuming that rationalists are right in thinking that the development of science reduces the room for religion (and Durkheim seems to be sharing this view), science, in its development, never makes up a wholly coherent system. New observations have to be interpreted and incorporated into the scientific thinking system, and as this is happening, there emerge more observations and more ideas and so on - there is never full coherence. However, people do want a coherent worldview - which can be provided only by

${ }^{75}$ The apocryphal quote from Chesterton is likely based on two phrases from the story The Oracle of the Dog. See the discussion about the origins of the quote on the website of the American Chesterton Society, 〈http://www.chesterton.org/ceases-to -worship/> [accessed 13 January 2015].

${ }^{76}$ In this case I agree with Stanisław Kozyr-Kowalski’s criticism, 'Weberowska socjologia religii a teoria społeczeństwa jako całości', in Max Weber, Szkice z socjologii religii, transl. Jerzy Prokopiuk and Henryk Wandowski, ed. Stanisław Kozyr-Kowalski, Warsaw, 1984, pp. 7-68, (pp. 25-26). Similar criticism of Weber's concept of rationalism can be found in J.C.D. Clark, 'Secularization and Modernization', p. 177. 
religion. ${ }^{77}$ I think that this argument is pertinent and sufficient to reject the thesis of inevitable secularization. Perhaps the notion of changing forms of symbiosis between religion and secular culture or the not too serious metaphor of marriage of convenience from the title of this study would be the most appropriate here.

(Translated by Anna Kijak)

\section{Summary}

The paper examines the problem of Dechristianization and secularization in nineteenth-century Europe, with a special emphasis on the Roman Catholic Church's ways of reacting to modernity. The first part deals with changes in religious attitudes, on individual and collective levels, in the midst of rapid social and intellectual changes that took place in the nineteenth century. The building of the modern secular state structures was among the most important factors weakening the position of the established churches.

The second part of the paper deals with the Roman Catholic Church. The argument of the author is that the Church managed to come to terms with modernity and to escape secularization at the price of supporting modern radical nationalism in the early twentieth century. The Church, especially since the times of Pope Leo XIII, chose to embrace modernity in its conservative form as an alternative to the dominant rationalist-liberal type. It was, nevertheless, a modernity, and the transformations of the Catholic Church throughout the nineteenth and early twentieth centuries should be understood in terms of modernization (although unenthusiastic) rather than resistance to modernity. The problem of Catholic liberalism and the reasons for its rather moderate influence are also discussed. On the whole, Peter Berger was right in saying that 'modernity is not necessarily secularizing; it is necessarily pluralizing', that is it creates various possibilities of behaviour that can, but do not have to, lead to secularization.

(Translated by MaciejJanowski)

\section{Bibliography}

Allport, Gordon W., 'Jednostka i religia', transl. Anna Bartkowicz and Irena Wyrzykowska, in idem, Osobowość i religia, Warsaw: Instytut Wydawniczy Pax, 1988, pp. 85-223.

Arnold, Claus, Mała historia modernizmu, Cracow: Wydawnictwo WAM, 2009.

77 Émile Durkheim, Elementarne formy życia religijnego. System totemiczny w Australii, transl. Anna Zadrożyńska, Warsaw, 2010 (French original: Les formes élémentaires de la vie religieuse. Le système totémique en Australie, Paris, 1912), pp. 369-70. 
Aronson, Eliot, Człowiek - istota społeczna, transl. Józef Radzicki, Warsaw: Państwowe Wydawnictwo Naukowe, 1978.

Aubert, Roger, et al., Historia Kościoła, 5 vols, Warsaw: Instytut Wydawniczy Pax, 1984-88, vol. 4: 1715-1848, vol. 5: 1848 do czasów współczesnych.

Auduc, Arlette, 'Une difficile construction d'église en banlieue: l'exemple de Sainte-Marthe des Quatre Chemins à Pantin (1875-1897)', Revue d'histoire de l'Église de France, 85, 1999, 215, pp. 291-314.

Barańska, Anna, Między Warszawa, Petersburgiem i Rzymem. Kościół a państwo w dobie Królestwa Polskiego, Lublin: Towarzystwo Naukowe Katolickiego Uniwersytetu Lubelskiego Jana Pawła II, 2008.

Berger, Peter L., 'Secularization Falsified', First Things, February 2008, pp. 23-27.

Bismarck, Otto von, Gedanken und Erinnerungen, 3 vols, Berlin and Stuttgart: Cotta, 1921-22.

Blaschke, Olaf, 'Das 19. Jahrhundert: Ein Zweites Konfessionelles Zeitalter?', Geschichte und Gesellschaft, 26, 2000, 1, pp. 38-65.

Brundell, Barry, 'Catholic Church Politics and Evolution Theory, 1894-1902', British Journal for the History of Science, 34, 2001, 1 (March), pp. 81-95.

Buszko, Józef, Sejmowa reforma wyborcza w Galicji, 1905-1914, Warsaw: Państwowe Wydawnictwo Naukowe, 1956.

Butterwick-Pawlikowski, Richard, 'Między oświeceniem a katolicyzmem, czyli o katolickim oświeceniu i oświeconym katolicyzmie’, Wiek Oświecenia, 30, 2014, pp. 11-55.

Chadwick, Owen, The Secularization of the European Mind in the 19th Century, Cambridge: Cambridge University Press, 1990.

Clark, Christopher, 'The New Catholicism and the European Culture Wars', in Culture Wars. Secular-Catholic Conflict in Nineteenth-Century Europe, ed. Christopher Clark and Wolfram Kaiser, Cambridge: Cambridge University Press, 2003, pp. 11-46.

Clark, Jonathan C.D., 'Secularization and Modernization: The Failure of a Grand Narrative', Historical Journal, 55, 2012, 1, pp. 161-94.

Dębicka, Elżbieta, Genealogia psychiczna, ed. Jerzy Komorowski, Wrocław: Wydawnictwo Uniwersytetu Wrocławskiego, 2012.

Draper, John William, History of the Conflict Between Religion and Science, New York: Appleton, 1875.

Dupanloup, Félix, La Convention du 15 Septembre et l'encyclique du 8 Décembre, Paris: Douniol, 1865.

Durkheim, Émile, Elementarne formy życia religijnego. System totemiczny $w$ Australii, transl. Anna Zadrożyńska, Warsaw: Wydawnictwo Naukowe PWN, 2010.

Fasora, Lukaš, 'Sociální souvislosti procesu sekularizace v málych komunitách v letech 1890-1913’, in Sekularizace českých zemí v letech 1848-1914, ed. Lukaš Fasora, Jiří Hanuš and Jiří Malír. Brno: Centrum pro studium demokracie a kultury, 2007, pp. 35-48.

Gilson, Étienne, Historia filozofii chrześcijańskiej w wiekach średnich, Warsaw: Instytut Wydawniczy Pax, 1987. 
Górski, Karol, Zarys dziejów duchowości w Polsce, Cracow: Wydawnictwo Znak, 1986. Gross, Michael B., 'Kulturkampf and Unification: German Liberalism and the War Against the Jesuits', Central European History, 30, 1997, 4, pp. 545-66.

Hazareesingh, Sudhir, 'Religion and Politics in the Saint-Napoleon Festivity (1852-1870): Anti-Clericalism, Local Patriotism and Modernity’, English Historical Review, 119, 2004, 482 (June), pp. 614-49.

Hennesey SJ, James, 'Leo XIII: Intellectualizing the Combat with Modernity', U.S. Catholic Historian, 7, 1988, 4 (Fall), pp. 393-400.

Himmelfarb, Gertrude, Lord Acton, Chicago: Routledge \& Paul, 1952.

Jedlicki, Jerzy, Świat zwyrodniały. Lęki i wyroki krytyków nowoczesności, Warsaw: Sic!, 2000.

J.N. [Jan Nowodworski], 'Narodowość', in Encyklopedia kościelna podług teologicznej encyklopedii Wetzera $i$ Weltego z licznymi jej dopetnieniami, ed. Rev. Michał Nowodworski, 33 vols, Warsaw: [n. pub.], 1873-1933, vol. 15, 1883, pp. 548-58.

Kehrer, Günter, Wprowadzenie do socjologii religii, transl. Janusz Piegza, 2nd edn, Cracow: Zakład Wydawniczy Nomos, 2006.

Kozyr-Kowalski, Stanisław, 'Weberowska socjologia religii a teoria społeczeństwa jako całości', in Max Weber, Szkice z socjologii religii, transl. Jerzy Prokopiuk and Henryk Wandowski, ed. Stanisław Kozyr-Kowalski, Warsaw: Książka i Wiedza, 1984, pp. 7-68.

Łazuga, Waldemar, Michał Bobrzyński. Myśl historyczna a działalność polityczna, Warsaw: Państwowe Wydawnictwo Naukowe, 1982.

Montalembert, Charles de, Catholic Interests in the Nineteenth Century, London: Dolman, 1852.

Montalembert, Charles de, Des intérêts catholiques au XIX ${ }^{e}$ siècle, Brussels: Meline, Cans, 1852.

Newman, John Henry, Letter to J. Walker of Scarborough, 22 May 1868, in The Letters and Diaries of John Henry Newman, 32 vols, London: T. Nelson; Oxford: Oxford University Press, 1961-2008, vol. 24: A Grammar of Assent: January 1868 to December 1869, ed. Charles Stephen Dessain and Thomas Gornall, Oxford, 1973, pp. 77-78.

Murphy, Terrence, 'Lord Acton and the Question of Moral Judgments in History: The Development of His Position', Catholic Historical Review, 70, 1984, 2 (April), pp. 225-50.

Nipperdey, Thomas, Deutsche Geschichte 1800-1866, Munich: Beck, 1998.

O'Connell, Marvin R., Critics on Trial. An Introduction to the Catholic Modernist Crisis, Washington, DC: Catholic University of America Press, 1994.

O'Connell, Marvin R., 'Ultramontanism and Dupanloup: The Compromise of 1865', Church History, 53, 1984, 2 (June), pp. 200-17 (p. 204).

Olszewski, Daniel, Kultura i życie religijne społeczeństwa polskiego w XIX wieku, Lublin: Wydawnictwo KUL, 2014.

Ostrowski, Witold, 'Książka z Littlemore' [introduction], in John Henry Newman, O rozwoju doktryny chrześcijańskiej, Warsaw: Instytut Wydawniczy Pax, 1957, pp. 5-18. 
Parandowski, Jan, Niebo w płomieniach, 13th edn, Warsaw: Czytelnik, 1976.

Pawluczuk, Włodzimierz, Światopoglad jednostki w warunkach rozpadu społeczności tradycyjnej, Warsaw: Państwowe Wydawnictwo Naukowe, 1972.

Péter, László, 'Church-State Relations and Civil Society in Hungary. A Historical Perspective,' in László Péter, Hungary's Long Nineteenth Century. Constitutional and Democratic Traditions in a European Perspective. Collected Studies, ed. Miklós Lojkó, Leiden and Boston: Brill, 2012, pp. 405-37.

Péter, László, 'Hungarian Liberals and Church-State Relations', in Hungary and European Civilization, ed. György Ránki, Budapest: Akadémiai Kiadó, 1989, pp. 79-138.

‘Pismo XX Biskupów polskich', Czas, 66, 17 April 1913, no. 177, afternoon edition, p. 1.

Porter-Szücs, Brian, Faith and Fatherland. Catholicism, Modernity and Poland, New York: Oxford University Press, 2011.

Romanowiczówna, Zofia, Dziennik lwowski 1842-1930, ed. Zbigniew Sudolski, 2 vols, Warsaw: Wydawnictwo Ancher, 2005.

Smout, Thomas Christopher, A Century of the Scottish People 1830-1950, London: Collins, 1986.

[Teodorowicz, Józef], Stańczyk bez teki. Odpowiedź na 'Dialog o zasadach i kompromisach', Warsaw: [n. pub.], 1917.

Veuillot, Louis, The Liberal Illusion, Washington, DC: National Catholic Welfare Conference, 1939.

Veuillot, Louis, L'illusion libérale, 5th edn, Paris: Palmé, 1866.

Zaleska, Ilona, Kościół a Narodowa Demokracja w Królestwie Polskim do wybuchu I wojny światowej, Warsaw: Wydawnictwo DiG, 2014.

Zamoyska, Jadwiga, Wspomnienia, ed. Maria Czapska, London: Świderski, 1961.

Zielińska, Katarzyna, Spory wokół teorii sekularyzacji, Cracow: Zakład Wydawniczy Nomos, 2009.

Żarnowska, Anna, Robotnicy Warszawy na przełomie XIX i XX wieku, Warsaw: Państwowy Instytut Wydawniczy, 1985.

Zdziechowski, Marian, Pesymizm, romantyzm a podstawy chrześcijaństwa, 2 vols, Cracow: [n. pub.], 1914.

Zieliński, Zygmunt, Papiestwo i papieże dwóch ostatnich wieków, 2nd edn amended, 2 vols, Poznań: Księgarnia Świętego Wojciecha, 1986.

Biography: Maciej Janowski - Professor at the Tadeusz Manteuffel Institute of History, Polish Academy of Sciences in Warsaw; Visiting Professor at the Department of History Central European University in Budapest. Scholarly interests: history of historiography, history of ideas in the nineteenth and twentieth century, Habsburg Monarchy. E-mail: janowskim@ceu.hu. 